\title{
6306 SAYILI KANUN BAKIMINDAN KENTSEL DÖNÜŞÜM SÜRECİ ve TAPU SİCİL İŞLEMLERİ BAKIMINDAN DEĞERLENDİRILMESI
}

\author{
URBAN TRANSFORMATION PROCESS FROM THE STANDPOINT OF \\ LAW NO. 6306 AND EVALUATION OF LAND REGISTRY \\ TRANSACTIONS IN REGARD TO LAW NO. 6306
}

DOI: $10.21492 /$ inuhfd.342843

\begin{abstract}
Osman Levent ÖZAY* Feride DEMIRBAŞ ${ }^{* *}$

Özet

Kentsel dönüşüm, ekonomik, siyasi, sosyal, kültürel ve hukukî açıdan önemli sonuçlar doğuran çok yönlü bir kavramdır. Kavramın hukukî yönünün ve sonuçlarının şekillenmesinde en önemli rolü 16.5.2012 tarihinde yürürlüğe giren 6306 Sayılı Afet Riski Altındaki Alanların Dönüştürülmesi Hakkında Kanun ve 6306 Sayılı Kanun'un Uygulama Yönetmeliği oluşturmaktadır. Bu düzenlemelerde, mülkiyet ve tapu sicil hukukunun temel ilkelerine istisna teşkil eden ve kişilerin mülkiyet hakkına çeşitli müdahaleler içeren hükümler bulunmaktadır. $\mathrm{Bu}$ hükümlerin bazıları Anayasa Mahkemesi tarafindan incelenmiş ve iptal edilmiştir. Hâlihazırda Kanun'un mülkiyet ve tapu sicil hukukuna ilişkin hükümleri çeşitli sakıncaları bünyesinde barındırmaktadır.

$\mathrm{Bu}$ çalışmada öncelikle kentsel dönüşümün ne olduğu ve 6306 Sayılı Kanun kapsamında kentsel dönüşümden ne anlaşılması gerektiği üzerinde durulmuştur. Ardından 6306 Sayılı Kanun'a göre kentsel dönüşümün hangi hukukî aşamalarda gerçekleştiğinin ve son olarak bu süreçlerde yer alan tescil, şerh, beyan ve terkin şeklindeki tapu sicil işlemlerinin hukukî nitelikleri incelenmiştir. $\mathrm{Bu}$ çalışmanın nihai amacı kentsel dönüşümün her bir aşamasında gerçekleşen tapu sicil işlemlerinin tapu sicil hukukunun genel prensipleri bakımından incelenmesi ve eleştirilerin ortaya konmasıdır.
\end{abstract}

Anahtar Kelimeler: Kentsel Dönüşüm, Tapu Sicili, Tescil, Şerh, Beyan, Terkin.

Abstract

Urban transformation is a multifaceted concept that has important economic, political, social, cultural and legal consequences. The most important role in the shaping of the legal direction and results of the concept is the Law No. 6306 on the Conversion of Disaster Relief Areas and the Implementing Regulation of the Law No. 6306 which took effect on 16.5.2012. There are provisions in these regulations which are an exception to the basic principles of property and land registry law, and which contain various interventions

\footnotetext{
*Akdeniz Üniversitesi Hukuk Fakültesi Medeni Hukuk Anabilim Dalı Araştırma Görevlisi, levent.ozay@hotmail.com.

**Akdeniz Üniversitesi Hukuk Fakültesi Medeni Hukuk Anabilim Dalı Araştırma Görevlisi, feridedemirbas@gmail.com.
} 
to the property rights of persons. Some of these provisions have been reviewed by the Constitutional Court and have been canceled. At present the law's provisions on ownership and the land registry law has various drawbacks.

In this study, first of all, what urban transformation is and what should be understood from urban transformation within the scope of Law No. 6306 is emphasized. Then, according to Law no. 6306, the legal qualifications of urban transformation and finally the legal qualifications of registration, annotations, statements and annulment in these processes is examined. The final purpose of this study is to investigate and criticize the land registry transactions according to the general principles of land registry law in all stages of urban transformation.

Keywords: Urban Transformation, Land Registry, Registration, Annotations, Statements, Annulment.

\section{KENTSEL DÖNÜŞÜM VE TÜRK HUKUK MEVZUATINDAKİ YERİ}

Kentsel dönüşüm kavramı, Türk Dil Kurumunun Güncel Türkçe Sözlüğü’nde, "Kentin imar planına uymayan, ruhsatsı binaların yıkılıp, planlara uygun olarak toplu yerleşim alanlarının oluşturulması" şeklinde tanımlanmıştır ${ }^{1}$. Ancak, bu tanım şehir ve bölge planlaması bakımından yeterli bir tanım değildir. Bu noktada, yapılan bir başka tanıma göre ${ }^{2}$, kentsel dönüşüm, "çökme ve bozulma olan kentsel mekânın ekonomik, toplumsal, fiziksel ve çevresel koşulların kapsaml ve bütünleşik yaklaşımlarla iyileştirmeye yönelik uygulanan strateji ve eylemlerin bütünüdür." şeklinde tanımlanmaktadır. Anılan tanım, kentsel mekânın sosyal anlamda kalkınmasını da içeren ve kentsel dönüşümü sadece mekânsal olarak görmeyen niteliktedir.

Bir diğer tanımda ise ${ }^{3}$, "kentin eskimiş veya kullanılamaz hale gelmiş bir bölgesinin yaşama kazandırılması" olarak tanımlanmaktadır. Yine bir diğer tanıma göre ${ }^{4}$, "kentsel dönüşüm, kentsel çöküntü alanlarında yoğunlaşan sorunların eşgüdümlü çözümüne yönelik yöntemdir".

\footnotetext{
${ }^{1}$ http://www.tdk.gov.tr/index.php?option=com_gts\&arama=gts\&guid=TDK.GTS.59ba5fc4 c4e6a6.45412078, E.T.: 30.08.2017.

${ }^{2}$ AKKAR, Z. Müge, "Kentsel Dönüşüm Üzerine Batı'daki Kavramlar, Tanımlar, Süreçler ve Türkiye", Şehir Plancıları Odası Planlama Dergisi, S. 36, Y. 2006/2, s. 29.

3 ÜSTÜN, Gül, Kentsel Dönüşüm Hukuku, On iki Levha Yayınları, İstanbul 2014, s. 4. Özellikle dn. 8'de belirtilen yazar.

${ }^{4}$ SARAÇ, Murat, Kentsel Dönüşüm ve Gelişimi, Sosyal Boyutu, Kentsel Dönüşümden Doğan Hukukî Sorunlar, Çankaya Üniversitesi Sosyal Bilimler Enstitüsü Özel Hukuk Anabilim Dalı Yayımlanmamış Yüksek Lisans Tezi, Ankara 2014, s. 11 dn. 20.
} 
Akademik ve mesleki literatürde kentsel dönüşüme ilişkin çeşitli tanımlar yer almaktadır 5 . Bu çeşitliliğe rağmen, herkes tarafından kabul edilen bir tanıma da rastlanmamaktadır. Anılan durum, esasında kentsel dönüşümün yenileme, yeniden canlandırma, eski haline getirme, soylulaştırma $\mathrm{vb}$. gibi farklı faaliyetlerden oluşan çatı nitelikte bir kavram olmasından kaynaklanmaktadır. Ayrıca, kentsel dönüşümün hangi disiplin bakımından ele alındığı da tanımını farklılaştırabilmektedir ${ }^{6}$.

Kentsel dönüşüme ilişkin yeni bir tanım yapmak çalışmamızın sınırlarını aşmakla birlikte, kentsel dönüşümün temel amacının, kentlerde yaşam kalitesinin yükseltilerek, o kentte yaşayanlara bu kalitenin eşit bir şekilde dağıtılması olarak özetlenebilir ${ }^{7}$. Ancak, ülkemizde uygulanan kentsel dönüşüm politikasının sosyal ve ekonomik unsurdan çok fiziksel iyileştirmeyi merkeze aldığını söylemek yanlış olmaz.

\section{6306 SAYILI KANUN BAKIMINDAN KENTSEL DÖNÜŞÜM}

Türk hukukunda kentsel dönüşüme ilişkin genel ve ayrıntılı düzenlemelerin başında 6306 sayılı Kanun gelmektedir ${ }^{8}$. 6306 Sayılı Kanun bakımından kentsel dönüşümün amac1, "Amaç" başlıklı 1. maddede, "Bu Kanunun amacl; afet riski altındaki alanlar ile bu alanlar dışındaki riskli yapıların bulunduğu arsa ve arazilerde fen ve sanat norm ve standartlarına uygun, sağllklı ve güvenli yaşama çevrelerini teşkil

\footnotetext{
${ }^{5}$ Farklı tanımlar için bkz. SARAÇ, s. 10 vd.; AKKAR, s. 29 vd.; ÇAKALLI, Mehmet Emin, Kentsel Dönüşüm Projeleri ve İlgili İdari Yarg1 Kararları, Adalet Yayınevi, Ankara 2013, s. 18 vd.; ÜSTÜN, s. 3 vd.; DINÇER, Billur, Kentsel Dönüşüm ve Sosyal Adalet, Galatasaray Üniversitesi Sosyal Bilimler Enstitüsü Kamu Hukuku Anabilim Dalı Yayımlanmamış Yüksek Lisans Tezi, İstanbul 2014, s. 81 vd.; ATEŞ, Turan., 2/B'lerin Satış1 ve Kentsel Dönüşüm, Bilge Yayınevi, Ankara 2013, s. 131; GENÇ, Fatma Neval, “Türkiye'de Kentsel Dönüşüm: Mevzuat ve Uygulamaların Genel Görünümü”, Yönetim ve Ekonomi Manisa Celal Bayar Üniversitesi İktisadi ve İdari Bilimler Fakültesi Dergisi, C.15, S. 1, Y. 2008, s. $121 \mathrm{vd.}$

${ }^{6}$ Kentsel dönüşümün esasında bir imar uygulaması olduğu noktasında bkz. ÇAKALLI, s. 20.

${ }^{7}$ DINÇER, s. 86; ÜSTÜN, s. 51.

${ }^{8}$ Kentsel dönüşüm kavramını içeren ilk düzenleme, hukukumuzda 5104 Sayılı Kuzey Ankara Girişi Kentsel Dönüşüm Projesi Kanun'udur. Ancak, kentsel dönüşümle ilgili olarak çeşitli hükümleri uygulama alanı bulan kanunlar da yer almaktadır. Buna, 5393 Sayılı Belediye Kanunu, 2985 Sayılı Toplu Konut Kanunu, 5216 Sayılı Büyükşehir Belediyesi Kanunu, 5366 Sayılı Yıpranan Tarihi ve Kültürel Taşınmaz Varlıklarının Yenilenerek Korunması ve Yaşatılarak Kullanılması Hakkında Kanun örnek gösterilebilir.
} 
etmek üzere iyileştirme, tasfiye ve yenilemelere dair usul ve esaslar belirlemektir." olarak açıklanmaktadır ${ }^{9}$. Bu noktada, Kanun esasında afet riski altında olan alanlar ile bu alanların dışında yer alan riskli yapıların dönüşümünü ${ }^{10}$ amaçlamaktadır $^{11}$. Bu anlamda, 6306 Sayılı Kanun'un amacından anlaşıldığı üzere, kentsel dönüşümle esas hedeflenen, var olan yapıların iyileştirilmesi, yenilenmesi, hatta gerektiğinde mevcut yapıların tasfiye edilmesidir ${ }^{12}$.

\section{KENTSEL DÖNÜŞÜMDE TEMEL KAVRAMLAR: RİSKLI ALAN, RİSKLI YAPI VE REZERV YAPI ALANI}

6306 Sayılı Kanun'un kentsel dönüşüm politikalarından biri olduğunu yukarıda açıklamıştık. Bu anlamda, Kanun'un dönüşümü hedef tuttuğu alan ve yapılar, "Amaç" başlıklı birinci maddesinden anlaşılabilmektedir. Bu noktada, riskli alan ve riskli yapı kavramları ile karşılaşılmaktadır. Bu kavramlar dışında, rezerv yapı alanı da düzenlenmiştir. Rezerv yapı alanları, esasında riskli alan ve yapılardakinin aksine, riske ilişkin teknik raporun gerekmediği ve Çevre ve Şehircilik Bakanlığının karar verdiği alanlardır. Kanunda tanımlanmış olan bu alanlar aşağıda ayrıntılı olarak incelenmiştir.

9 KARAKOCALI, Ahmet/TOKBAŞ, Hakan/SENCER, Sıla/KURŞUN, Ali Suphi, Sorularla Kentsel Dönüşüm Hukuku, Aristo Yayınevi, İstanbul 2017, s. 3.

${ }^{10}$ ÇOLAK, Nusret İlker, "Kentsel Dönüşüm/Kenti Dönüştürme ve Uygulanma Şekilleri”, Kocaeli Üniversitesi Hukuk Fakültesi Dergisi, C.4, S.7, Y. 2013, s. 7-24 (Tam metin için bkz. https://www.jurix.com.tr/article/4378 E.T.: 03.09.2017). Yazar, anılan eserinde, dönüşüm ifadesi yerine dönüştürme ifadesinin doğru olduğunu, zira dönüşüm kavramının zorlama olmadan, takvim ve plana bağlı kalmaksızın mevcut durumun değişmesi olduğunu ileri sürmektedir. Kanaatimizce, yazar, kelime anlamı olarak doğru bir noktaya işaret etmektedir. Fakat kanun koyucunun benimsediği terim dönüşüm olduğu için, bu çalışmada esas alınan terim de dönüşüm terimidir.

${ }^{11}$ DİNÇER, s. 202.

${ }^{12}$ Kentsel dönüşüme ilişkin müdahale şekilleri farklı sınıflandırmalara tabi tutulmakta ve hatta tam olarak kavramlar birbirleriyle örtüşmemektedir. Ancak, genel kabule göre müdahale şekilleri sınıflandırıldığında, -kentsel yenileme, -kentsel canlandırma, -kentsel yeniden üretim, -soylulaştırma türleri ile karşılaşılmaktadır. Kentsel yeniden üretim, günümüzde kentsel dönüşüm anlamında kullanılan müdahale şekli olup, ülkemizde de yeniden üretime ilişkin projeler gerçekleştirilmektedir. Yeniden üretim kavramından, alanın tamamen yıkılması ve yeniden yapılması anlaşılmaktadır. Ayrıntılı bilgi için bkz. DİNÇER, s. 88 vd. 


\section{A. Riskli Alan}

6306 Sayılı Kanun m. 2/I/ç riskli alanı, "Zemin yapısı veya üzerindeki yapılaşma sebebiyle can ve mal kaybına yol açma riski taşıyan, Bakanlık veya Idare tarafindan Afet ve Acil Durum Yönetimi Başkanlı̆̆ının uygun görüşü de alınarak belirlenen ve Bakanlığın teklifi üzerine Bakanlar Kurulunca kararlaştırılan alan" olarak tanımlanmıştır. Aynı tanım, 6306 Sayılı Kanun'un Uygulama Yönetmeliği'nde ${ }^{13}$ (Yönetmelik) de benimsenmiştir (Yönetmelik, m. 3/I/f).

Riskli alanların tespitinde uygulamanın ne şekilde olacağ 1 Yönetmelik'in 5. maddesinde düzenlenmiş ve anılan hükmün dördüncü fikrasında, taşınmaz maliki olan gerçek veya özel hukuk tüzel kişilerinin de Bakanlık veya İdareden riskli alan tespit talebinde bulunabilecekleri hükme bağlanmıştır.

Bir alanın riskli alan olarak ilan edilebilmesi için gereken şartlar, Yönetmelik m. 5/I,II'de iki farklı çerçeveden düzenlenmektedir. Hükmün birinci fikrasına göre, riskli alanın, yapılaşma sebebiyle can ve mal kaybına yol açabileceğine ilişkin teknik raporun bulunması gerekmektedir. İkinci fikradaysa, Bakanlıkça, kamu düzeni veya güvenliğinin olağan hayatı durduracak veya kesintiye uğratacak şekilde bozulduğu yerlerde veya üzerindeki toplam yapı sayısının en az \%65'inin imar mevzuatına aykırı veya yapı ruhsatı alınmaksızın inşa edildiği ve sonradan yapı ve iskân ruhsatı alan yapılardan oluşan bölgelerin riskli alan olarak bakanlar kuruluna teklif edilebileceği düzenlenmiştir ${ }^{14}$. Söz konusu Yönetmelik hükmüyle, kentsel dönüşümün konusu olabilecek alanlar bakımından şartlar, daha açık ve net bir şekilde ihdas edilmiştir ${ }^{15}$. Ayrıca riskli alanların tespiti konusunda, Kanun'da ve Yönetmelik'te belediye-

\footnotetext{
${ }^{13}$ RG. T. 15.12 .2012 S. 28498.

${ }^{14}$ Anılan hüküm, RG. T. 26.04.2016, S. 29695. Resmi Gazetede yayınlanan 6704 Say1lı Kanun ile 6306 Sayılı Kanuna Ek Madde 1 olarak eklenmiştir ve Yönetmelik’te yer alan hüküm de T. 27.10.2016, S. 29870 Resmi Gazetede yayınlanan yönetmelik değişikliği ile gerçekleşmiştir.

${ }^{15}$ Zira Yönetmelik hükmü,T. 27.10.2016, S. 29870 Resmi Gazete'de yayınlanan "6306 Kanunun Uygulama Yönetmeliğinde Değişiklik Yapılmasına Dair Yönetmelik" ile değiştirilmiştir. Eski düzenlemede, "Bir alanın riskli alan olarak tespit edilebilmesi için alanın büyüklügüüün asgarî $15.000 \mathrm{~m} 2$ olması gerekir. Ancak, Bakanlıkça uygulama bütünlügü bakımından gerekli görülmesi halinde, parsel veya parsellerin büyüklüğüne bakılmaksızın ve $15.000 \mathrm{~m} 2$ şartı aranmaksızın riskli alan tespiti yapılabilir." ifadesi ile yalnızca yüzölçümüne ilişkin şart bulunmaktaydı.
} 
köy ayrımı yapılmaksızın her tip alanın riskli alan olarak ilan edilmesine cevaz verilmektedir ${ }^{16}$.

6306 Sayılı Kanun m.3/III hükmü uyarınca, bir alanın riskli alan olarak ilan edilmesi halinde, bu alanda bulunan Hazinenin özel mülkiyetindeki taşınmazların Bakanlığın talebi ile Bakanlığa tahsis imkânı sağlanmıştır. Hatta aynı şekilde TOKİ ve İdareye bedelsiz olarak devredilebilmesine imkân tanınmıştır. Dolayısıyla, bu düzenleme ile riskli alan ilan edilen yerlerde bulunan kamusal alanların da yapılaşmaya açılabileceği sonucu çıkarılmaktadır ${ }^{17}$. Ayrıca, riskli alan kapsamında yer alan riskli kamu binaları da dönüşüm kapsamındadır ${ }^{18}$.

Kanun'un temel kavramlarından olan riskli alana ilişkin iki değişikliğin de incelenmesi gerekmektedir. Bunlardan ilki, 14.04.2016 tarihli 6704 Sayılı Kanun'un ${ }^{19}$ 21. maddesiyle 6306 Sayılı Kanun'un 3. maddesine eklenen fikradır. 6306 Sayılı Kanun'un m.3/VII hükmü, " $B u$ Kanunun uygulanması için belirlenen alanların sinırlart içinde olup riskli yapılar dışında kalan diğer yapılardan uygulama bütünlüğü bakımından Bakanlıkça gerekli görülenler, değerleme çalışmalarında yapının riskli olmadı̆̆ l gözetilmek kaydlyla bu Kanun hükümlerine tabi olur." ifadesini içermektedir ${ }^{20}$. Söz konusu hüküm uyarınca, Kanun kapsamına yalnızca riskli yap1 ve alanlar değil, risk taşımayan fakat riskli alanda yer alan taşınmazlar da eklenmiştir ki bu durum Kanun'un "Amaç" başlıklı 1. maddesi ile çelişki yaratmaktadır. Oysa aynı hüküm 6306 Sayılı Kanun'un ilk halinde de mevcut olup Anayasa Mahkemesi'nin 27.02.2014 tarihli

\footnotetext{
${ }^{16}$ Hatta Kanun m. 9/II hükmü, Anayasa Mahkemesi tarafindan iptal edilmesinden önce, bazı kanun isimleri sayılmış ve bu kanunların 6306 Sayılı Kanunu engelleyici hükümlerinin uygulanmayacağı hüküm altına alınmıştı. Ancak, Anayasa Mahkemesinin kararıyla bu hüküm iptal edildiği için, 6306 Sayılı Kanun kapsamında riskli alan ilanının kısıtlandığını söylenebilir. İlgili Anayasa Mahkemesi kararı için bkz. T. 27.2.2014, E. 2012/87, K. 2014/41, RG. T. 26.07.2014, S. 29072.

${ }^{17}$ Aynı yönde, DİNÇER, s. 205. Anayasa Mahkemesinin yukarıda anılan kararından öncesinde, hazine dışındaki kamu idarelerinin taşınmazlarının da Bakanlığa tahsis veya TOKİ ve İdareye devri söz konusu olabilmekteydi. (m. 3/IV).

${ }^{18}$ Ş่̇MŞEK, Suat, Türkiye'de Kentsel Dönüşüm Uygulamaları, Seçkin Yayıncılık, Ankara 2014 , s. 41.

${ }^{19}$ RG 26.04.2016 T. 29695 S.

${ }^{20}$ Söz konusu düzenleme, Anayasa Mahkemesi'nin T. 27.2.2014 , 2012/87 E. ve 2014/41 K. Sayılı kararı ile iptal edilmiş fakat 26.04.2016 T. 29695 S. Resmi Gazete'de yayınlanan 6704 Sayılı Kanun'un 21. maddesi ile tekrar m.3/VII olarak 6306 Say1l Kanuna eklenmiştir.
} 
karar1 ${ }^{21}$ ile iptal edilmişti. Kararda düzenlemeye ilişkin olarak, “...kanunla getirilen bu sınırlamanın, kamu yararı amacı taşıması dışında, kamunun yararı ile bireylerin temel haklar arasında kurulması gereken adil dengeyi bozmaması, ölçülü olması da gerekir. Dava konusu kuralla, "riskli olmayan yapılar" hakkında yapılacak uygulamalara ilişkin özel bir düzenleme öngörülmemiş, riskli yapılara ilişkin kurallara atıf yapılmıştır. Ancak anılan kurallar, yapiların riskli olmasl dikkate alınarak düzenlenmiş, kamu yararı ile bireylerin haklarl arasında buna uygun denge oluşturulmaya çalışılmıştır. Menfaatler dengesi bu şekilde oluşturulan kuralların riskli olmayan yapılara uygulanmast, Anayasa'nın 13. maddesinde temel hakların sinırlandırılmasının ölçütleri arasında yer verilen "ölçülülük" ilkesine aykırllı oluşturmakta ve kamu yararı ile riskli olmayan yap sahiplerinin haklart arasinda kurulmasi gereken dengeyi bozmaktadır." ifadelerine yer verilmiştir. Hükmün, Kanun'un amacı ile örtüşmediği öğretide de ileri sürülmektedir ${ }^{22}$. Ancak, kişilerin oturduğu yapının riskli olmaması halinde mülkiyet haklarına müdahalenin hukuki olmayan "uygulama bütünlüğü" gerekçesi yerine hangi hukuk kuralları ve ilkeleri doğrultusunda gerçekleştirileceğini açıklayan bir düzenleme daha yerinde olurdu.

Riskli alanlara ilişkin incelenmesi gereken değişikliklerden ikincisi de 6704 Sayılı Kanun ile 6306 Say1l Kanun'a eklenen Ek Madde $1^{23}$ dir. Hüküm, imar mevzuatına aykırı yapılaşmanın veya kamu düzeni veya

${ }^{21}$ Anayasa Mahkemesi T. 27.2.2014, E. 2012/87 ve K. 2014/41 Say1l karar1 (http://www.resmigazete.gov.tr/main.aspx?home=http://www.resmigazete.gov.tr/eskiler/ 2014/07/20140726.htm\&main=http://www.resmigazete.gov.tr/eskiler/2014/07/20140726 .htm) Bkz. RG T. 26.7.2014 S.29072.

${ }^{22}$ DİNÇER, s. 208.

${ }^{23}$ Ek Madde 1: (1) a) Kamu düzeni veya güvenliğinin olağan hayatı durduracak veya kesintiye uğratacak şsekilde bozulduğu yerlerde; planlama ya da altyap hizmetleri yetersiz olan veya imar mevzuatına aykirı yapılaşma bulunan yahut yapı ya da altyapısı hasarlı olan alanlar,

b) Üzerindeki toplam yap sayısının en az \%65'i imar mevzuatına aykirt olan veya yapı ruhsatı alınmaksızın inşa edilmiş olmakla birlikte sonradan yapı ve iskân ruhsatı alan yapılardan oluşan alanlar, fen ve sanat norm ve standartlarına uygun, sağllkll ve güvenli yaşama çevrelerini teşkil etmek, sağlık, eğitim ve ulaşım gibi kamu hizmetlerinin düzenli bir şekilde yürü̈tülmesini sağlamak amacıyla, Bakanlığın teklifi üzerine Bakanlar Kurulunca riskli alan olarak kararlaştırılabilir. Riskli alan sinırı uygulama bütünlüğ̈̈ gözetilerek belirlenir.

(2) a) Riskli alan kararına karşı Resmî Gazete'de yayımı tarihinden itibaren dava açılabilir. Uygulama işlemleri üzerine riskli alan kararma karşı dava açılamaz.

b) Birinci fikranın (a) bendi uyarınca belirlenen riskli alanlarda kamu kaynağl kullantlarak gerçekleştirilen her türlü mal ve hizmet alımları ile yapım işleri, 4734 Sayılı Kanunun 21 inci maddesinin birinci fikrasının (b) bendinde belirtilen hâllere dayanan işlerden Sayllır. 
güvenliğinin bozulduğu yerlerde dönüşümü sağlamak amaciyla ihdas edilmiştir. Hükümle birlikte, riskli alan olarak belirlenebilecek yerlerin kapsamının genişlediği konusunda tereddüt bulunmamaktadır. Ancak, kanaatimizce, anılan hüküm Kanun'un "Amaç" başlıklı birinci maddesine aykırıdır. Zira Kanun'un kapsamı 1. maddeye göre halen " afet riski altındaki alanlar ile bu alanlar dışındaki riskli yapıları"dır.. Ek Madde 1 kapsamında düzenlenen riskli alanlar ise, 1. maddede düzenlenen yerler kapsamında değildir.

\section{B. Riskli Yapı}

Riskli yapı, Kanun'un m. 2/I/d hükmünde, "Riskli alan içinde veya dışında olup ekonomik ömrünü tamamlamış olan ya da yıkılma veya ă̆ır hasar görme riski taşıdı ğ ilmi ve teknik verilere dayanılarak tespit edilen yapı" ifadesiyle tanımlanmıştır. Tanımdan anlaşılacağı üzere, riskli alanların aksine, herhangi bir idari kurumun riskli yapı konusunda karar vermesine gerek bulunmamakta, teknik verilerle tespitin yapılması yeterli olmaktadır. Ayrıca, riskli yapı tespitinin yapılması için, yapının mutlaka riskli alan içerisinde yer almasına da gerek bulunmamaktadır.

"Riskli yapl" kavramı Kanunda tanımlanmış ancak kavramın bir unsuru olan yapıdan ne anlaşılması gerektiği açıklanmamıştır. Mevzuatımızda, yapı kavramının tanımına sadece 3194 Sayılı İmar Kanunu m. 5'te şu şekilde yer verilmiştir: "karada ve suda, daimi veya muvakkat, resmi ve hususi yeraltı ve yerüstü inşaatı ile bunlartn ilave, değişiklik ve tamirlerini içine alan sabit ve müteharrik tesislerdir”. 6306 Sayılı Kanun bakımından da yapının tanımda belirtildiği şekilde geniş yorumlanması kanunun amacına uymaktadır ${ }^{24}$. Ancak, Yönetmelik m. 7/I, "Riskli yapr tespiti, kendi başına kullanilabilen, üstü örtülü ve insanların içine girebilecekleri ve insanların oturma, çalışma, eğlenme veya dinlenmelerine veya ibadet etmelerine yarayan yapılar ile hayvanlartn ve eşyaların korunmasına yarayan yapılar hakkında yapılır. İnşaat halinde olup ikamet edilmeyen yaplar ile metruk olmast veya bir kisminin yıkılması sebepleriyle yapı bütünlüğ̈̈ bozulmuş olan yapılar riskli yapı tespitine konu edilmez." ifadesini içermektedir. Düzenlenen tanım, 3194 sayılı İmar Kanun'unun 5. maddesinde yer alan "bina" tanımıdır ${ }^{25}$.

\footnotetext{
${ }^{24}$ Ayn1 yönde, ŞİMŞEK, s. 43.

${ }^{25}$ İmar Kanun'da bina, “kendi başına kullanılabilen, üstü örtülü ve insanların içine girebilecekleri ve insanları oturma, çalışma, eğlenme veya dinlenmelerine veya ibadet
} 
Kanaatimizce, kanun koyucunun riskli "yapı" kavramını tercih etmesi ve bu kavramın Türk hukuku bakımından karşıllğı bulunmaktayken, Yönetmelikle daha dar kapsamdaki "bina" tanımının riskli yapı bakımından benimsenmesi yerinde olmamıştır. Zira Yönetmelik hükmüne göre, riskli yap1 tespitine konu edilemeyen her türlü yap1, kentsel dönüşüm içerisinde değerlendirilmeyecektir ${ }^{26}$. Yönetmelik'te riskli yap1 bakımından çizilen sınır, yalnızca içerisinde insanların yaşadığı veya hayvan ve eşyaların korunmasına yarayan yapılardır. Afet durumunda yıkılma riski taşıyan ve bu kapsamda çevresine zarar verebilecek yapıların Kanun $\mathrm{m}$. 2/I/d gereğince dönüşüm kapsamına alınacağı hususunda kuşku yoktur. Oysa Yönetmelik hükmünde, yıkılma riski taşısa dahi inşaat halinde olup ikamet edilmeyen yapılar ile metruk olması veya bir kısmının yıkılması sebepleriyle yapı bütünlügü bozulmuş olan yapıların, riskli yap1 kapsamına alınmayacağı düzenlenmiştir. Diğer bir deyişle, Yönetmelikle riskli yapı kavramının dışında bırakılan "inşaat halinde olup ikamet edilmeyen yapılar ile metruk olması veya bir kısminin yılklması sebepleriyle yapı bütünlüğü bozulmuş olan yapı" ifadesi, Kanun'un öngörmediği bir sınırlama içermektedir. Kanaatimizce, Kanun'da yer almayan bir sınırlamanın Yönetmelik'te yer alması normlar hiyerarşisine uygun değildir. Bu nedenle, Yönetmelik’teki ifadenin dikkate alınmaması ve riskli yap1 tespitine konu edilemeyen yapıların da riskli yap1 kapsamında değerlendirilmesi uygun olur.

etmelerine yarıyan, hayvanların ve eşyaların korunmasına yarayan yapılardır. "ş̧eklinde tanımlanmıştır.

${ }^{26}$ Yönetmelik hükmüne göre, üstü örtülü olmadığı sürece, yapılar riskli yap1 tespitine konu edilememektedir. Ancak, isminde doğa olayları sonucu gerçekleşen yıkım anlamında kullanılan afet kelimesini içeren bir kanunun sadece üstü örtülü yapıları, yapı olarak değerlendirmesi çelişki meydana getirmektedir. Örneğin, alabalık çiftliğinin bulunduğu bir alanın, heyelan riski sebebiyle riskli yapı olarak tespiti mümkün olmayıp, anılan bölgede 6306 Sayılı Kanun kapsamında dönüşümün sağlanması imkân1 bulunmamaktadır. Oysa belirtilen alan da afet riski altında bulunup, dönüştürülmeye müsait bir yapıya sahip olabilir. Bu hususta, çiftliğin de dönüşüme dâhil edilebilmesi ancak, yönetmelik m. 7'de geçen "hayvanların ve eşyaların korunmasına yarayan yapılar" ifadesinin kapsamında değerlendirilmesi ve maddenin ilk cümlesinde yer alan "üstü örtülü" olma şartının sadece insanların kullandıkları yapılar bakımından aranan bir unsur olarak kabul edilmesiyle mümkündür. Ancak, her ne şekilde değerlendirme yapılırsa yapılsın, riskli yapı tespitine konu olmak için, yapının üstü örtülü olması şartının aranması, afetten sadece depremin anlaşıldığına delalet etmektedir. 


\section{Rezerv Yapı Alanı}

Rezerv yap1 alan1, 6306 Say11 Kanunu m. 2/I/c'de, “Bu kanun uyarınca gerçekleştirilecek uygulamalarda yeni yerleşim alanı olarak kullanılmak üzere, TOKI'nin veya İdarenin talebine bağlı olarak veya resen, Maliye Bakanlı̆̆ının uygun görüşü alınarak Bakanlıkça belirlenen alanlar" olarak tanımlanmışır. Rezerv yapı alanları, esasında riskli alan ve yapılarda ikamet edenlerin naklinin yapılacağ konut ve işyerleri ile bu alan ve yapılarda ikamet etmeyen kişilere satışın yapılabileceği yeni yerleşim alanları olarak kullanılabilen yerlerdir (Yönetmelik m. 4/IV). Rezerv yapı alanları, Bakanlar Kurulu kararı ile belirlenen riskli alanların aksine, doğrudan Bakanlık tarafindan belirlenmektedir. Aşağıda kentsel dönüşümün uygulanması başlığında rezerv yap1 alanlarında ne tip uygulamaların gerçekleştirilebileceği açıklanmıştır.

\section{KENTSEL DÖNÜŞÜMÜN UYGULANMASI}

6306 Sayılı Kanun'un mülkiyet hukuku bakımından incelenmesinden önce, dönüşümün nasıl gerçekleştiğinin açıklanması konunun anlaşılabilirliği bakımından önem arz etmektedir. Bu işlemlerden mülkiyet hukuku bakımından önem arz edenler aşağıda ayrıca incelenecektir.

\section{A. Tespit}

6306 Sayılı Kanun kapsamında kentsel dönüşüm işlemlerinin başlayabilmesi için öncelikle, riskli yapı ve alanların tespit edilmesi gerekmektedir. Kanun'un m.2/I/ç hükmüne göre, bir alanın riskli alan olduğuna karar verme yetkisi münhasıran Bakanlar Kurulu'na aittir. Bu yetkinin kullanımı ise, ancak Bakanlığın teklifi halinde mümkündür. Bakanlık bu noktada resen harekete geçebilir ya da taşınmaz maliki olan gerçek veya özel hukuk tüzel kişilerinin Bakanlık veya ilgili idareye başvurabilir (Yönetmelik, m. 5/IV).

Riskli yapıların tespiti hususunda ise, Kanun m. 3/I'e göre, öncelikle yap1 malikleri ${ }^{27}$ veya kanuni temsilcilerinin bu konuda lisanslandırılmış kurumlara tespit yaptırabileceği ve sonucu Bakanlık veya İdareye bildirmeleri gerektiği belirtilmiştir. Riskli yapı tespiti yaptırmak hususunda malikleri bağlayan herhangi bir süreye Kanun ve Yönetmelikte yer verilmemiştir. Ancak, Kanun'un anılan maddesinde, Bakanlığın tespit

${ }^{27}$ KARAKOCALI/TOKBAŞ/SENCER/KURŞUN, s. 25. (Yazarlar, riskli yap1 tespiti hususunda, birlikte mülkiyet hallerinde oybirliği gerektiğini fakat uygulamanın bunun aksine yanlış yönde ilerlediğini ileri sürmektedir, s. 26) 
yaptırmak konusunda malik veya kanuni temsilcilere süre verebileceği öngörülmüş olup, bu süre içerisinde maliklerce herhangi bir tespit yaptırılmadığı takdirde, tespitin Bakanlık veya İdarenin talebi ile gerçekleştirileceği düzenlenmiştir. Riskli yapı tespitinin yaptırılmasından sonra, raporlar Altyap1 ve Kentsel Dönüşüm Müdürlükleri tarafindan incelenerek, herhangi bir eksiklik bulunmaması halinde en geç on iş günü içinde Tapu Müdürlüğüne bildirilir ve Tapu Müdürlüğü tarafından ilgili yapının beyanlar hanesine gerekli belirtme gerçekleştirilir (Yönetmelik, m. 7/IV).

Riskli yapı tespitine ilişkin raporlara 15 gün içerisinde malik veya kanuni temsilcileri tarafından itiraz edilebileceği, Kanun m. 3/I'de düzenlenmiştir. Ancak, Kanunda belirtilen hükümde İdare veya Bakanlıkça yaptırılan riskli yapı tespitlerine itiraz imkânı tanınmışken, Yönetmelik'te bu konuda herhangi bir kısıtlama getirilmemiştir. Diğer bir deyişle, maliklerden biri tarafından yaptırılan tespite itiraz Kanunda düzenlenmemiştir. Oysa Yönetmelik’te, tespitin kim tarafından yaptırıldığına ilişkin bir kısıtlama olmaksızın riskli yapı tespiti ifadesine yer verilerek Kanun ve Yönetmelik arasında çelişki oluşturulmuştur. Kanaatimizce, kim tarafından yaptırıldığının önemi olmaksızın tüm tespit raporlarına karşı, itiraz imkânın tanınması, diğer bir ifadeyle Yönetmelik hükmünün dikkate alınması daha yerindedir.

Yönetmelik m. 7/V'e göre, itiraza ilişkin süre Tapu Müdürlüğü'nün gerekli işlemleri tamamlamas ${ }^{28}$ ve ayni ve şahsi hak sahiplerine tebligat yapmasından itibaren başlamaktadır. Anılan hükümden, hem ayni hem de şahsi hak sahiplerine tebligat yapılacağı ve itiraz edebilecekleri şeklinde anlam çıkmaktadır. Oysa Kanun m. 3/II'de ayni ve şahsi hak sahiplerine bilgi verileceği düzenlenmiştir. $\mathrm{Bu}$ hususta, Kanundaki ifadeler incelendiğinde, önce maliklerin itiraz haklarından bahsedilmiş, daha sonra ise, yapı üzerindeki ayni ve şahsi hak sahiplerine bilgi verileceği düzenlenmiştir. Yönetmelikte ise, ayni ve şahsi hak sahiplerine, bilgi ve itiraz edebileceklerine ilişkin tebligatın yapılacağından, daha sonra da maliklerin itiraz hakkından bahsedilmiştir. Bu noktada, Kanun ve Yönetmelik arasında bir çelişki bulunduğu açıktır. Kanaatimizce, hem

\footnotetext{
${ }^{28}$ Taşınmazın tapu sayfasındaki beyanlar hanesine belirtme yapılmasından sonra, tebligat gerçekleştirilecek olup, tapuda kayıtlı malikin ölmüş olması halinde, Bakanlık veya Müdürlük, TMK hükümlerine göre mirasçılık belgesi çıkartabilirler (Yönetmelik, m. $7 / \mathrm{V})$.
} 
itiraz konusu bakımından hem de itiraz edebilecek olan kişiler bakımından Yönetmelik m. 7/V, VI hükümlerinin dikkate alınması yerindedir. Böylece, hem ayni hem şahsi hak sahibi kişilerin raporlara karşı itiraz hakkı doğar ${ }^{29}$.

Riskli yapıların tespiti, Yönetmelik m. 6/I'de yer alan kurum ve kuruluşlar tarafından gerçekleştirilebilir ${ }^{30}$. Yönetmelik m. 7/III'te, her yapı için sadece bir adet riskli yapı tespit raporunun düzenlenebileceği ve buna ilişkin kurulan elektronik yazılım sisteminden kurumların anılan yap1 hakkında daha önceden rapor düzenlenip düzenlenmediğini görebilecekleri belirtilmiştir. Kanaatimizce, her yap1 için sadece bir raporun düzenlenmesi kuralı, Kanun'un amacı ile bağdaşmamaktadır. Zira bu konu doktrinde de mülkiyet hakkının kamu yararının gerektirdiğinden fazla ve makul olmayan bir şekilde kısıtlanması olarak yorumlanmaktadır ${ }^{31}$. Ayrıca, riskli yapı tespit raporuna karşı yapı malikinin 15 günlük süre içerisinde itiraz hakkı bulunurken, yine lisanslandırılmış farklı bir kurum veya kuruluştan tespit talebinde bulunma hakk1 yoktur. Bunun istisnasını Yönetmelik m. 7/III uyarınca, itiraz veya yargı kararı üzerine yeniden rapor tanzimi ve risk durumunu etkileyebilecek kasti bir müdahale halleri oluşturmaktadır.

\section{B. Tahliye, Yıktırma ve Tasarruf İşlemleri}

Riskli yapıların tespitine ilişkin itirazların reddedilmesi veya itiraz edilmemesi sonucunda tespit kesinleşir ${ }^{32}$ ve Altyapı ve Kentsel Dönüşüm

29 ŞIMŞEK, s. 61 (Yazar, itiraz konusu bakımından Yönetmelikte geçen m. 7/VI hükmünün esas alınması gerektiğini belirtmektedir.). Ayrıca, tespitlere ilişkin itirazlarda, itirazı inceleyecek olan teknik heyet, itiraz dilekçesinde gösterilen sebeplerle bağlı değildir (Yönetmelik, m. 10/VII).

30 "Riskli yapılar, a) Bakanlıkça, b) İdarece, c) Bakanlıkça lisanslandırılan, 1) Kamu kurum ve kuruluşlarl, 2) Üniversiteler, 3)Sermayesinin en az yüzde kırkı kamu kurum ve kuruluşlarına ait olan şirketler, 4) Depremden korunma, deprem zararlarının azaltılması ve deprem mühendisliğinin gelişmesine katkıda bulunmak gibi konularda faaliyet gösteren sivil toplum kuruluşlarl, 5) 29/6/2001 tarihli ve 4708 Sayılı Yapı Denetimi Hakkında Kanuna göre Bakanlıktan izin belgesi almış yapı denetimi kuruluşları ile laboratuar kuruluşlarl, 6) 27/1/1954 tarihli ve 6235 Sayll Türk Mühendis ve Mimar Odaları Birliği Kanunu uyarınca, inşaat, jeoloji ve jeofizik mühendisleri odalarına büro tescilini yaptırmış kurum ve kuruluşlar, tarafindan tespit edilir."

${ }^{31}$ ÖZSUNAY, Ergun, 6306 Sayılı Kanun ve Uygulamalarına İlişkin Düşünceler, Vedat Kitapçıllk, İstanbul 2015, s. 16.

32 İtirazın reddedilmesi kararına karşı idari yargıda, Kanun m. 6/IX hükmü gereği 30 gün içerisinde dava açılabilmekteyse de, sadece dava açılması yürütmenin durdurulması talep edilmedikçe işlemi durdurmayacağı için yıkıma ilişkin süreç başlamış olur. 
Müdürlüğü, idareden yapının yıktırılmasını ister (Yönetmelik, m. 8/I). Bu anlamda, tespitin yapı maliklerince veya Bakanlık ya da İdarece yapılması arasında herhangi bir fark bulunmamaktadır. Yapının riskli olduğunun kesinleşmesi ile birlikte, idare yıkım için gerekli idari işlemlere başlar. Yıkımdan önce maliklere 60 günden az olmamak üzere süre verilir. Bu süre içerisinde, maliklerin kiracı veya sınırlı ayni hak sahiplerini tahliye etmesi de gerekmektedir. Anılan sürede yıkım gerçekleştirilmezse, İdare tarafından otuz günden az olmak üzere ek süre verilerek yıkımın idari makamlarca gerçekleştirileceğine ilişkin tebligat yapılır. 60 günden az olmayan genel sürenin ve 30 günden az olan ek sürenin dolmasından itibaren yıkımın malikler tarafından gerçekleştirilmemesi durumunda, yapıya elektrik, su, doğalgaz hizmetlerinin kesilmesi için, İdare tarafindan talepte bulunulabilir.

Riskli yapıların yıkımına ilişkin anlaşma ile tahliyenin gerçekleştiği durumlarda, maliklere, kiracı veya sinırlı ayni hak sahiplerine, bu yapılarda ikamet edenler ile işyeri bulunanlara ve uygulamanın gerektirmesi halinde riskli yapıyı kullanmakta olan kişilere geçici konut veya işyeri tahsisi ya da kira yardımı yapılabileceği düzenlenmiştir (Kanun m. 5/I). Bu noktada, kanun koyucu, yapı maliklerini anlaşmaya teşvik eden yardımlara yer vermiştir.

Riskli yapıların belirlenmesinden sonra, yapının yıkılması zorunlu değildir. Kanun koyucu, bu tip yapılarda mümkünse yapının güçlendirilmesi yolunu da düzenlemiştir. Ancak, güçlendirme yapılabilmesi için, idare tarafından maliklere verilen süre içerisinde güçlendirmenin teknik olarak mümkün olduğunun tespit edilmesi ve maliklerin 4/5 çoğunlukla (KMK m.19/II) bu kararı almış olmaları, güçlendirme projesinin hazırlatılması ve imar mevzuatına göre ruhsat alınmas1 gerekmektedir.

Riskli yapıların gerek tespitlerinin gerekse yıkımlarının idare veya Bakanlıkça gerçekleştirilmesi halinde, masraflara ilişkin tapuda arsa paylarına ipotek koyulabileceği Kanun'da düzenlenmişti. Ancak, buna ilişkin hükümler Anayasa Mahkemesi kararı ${ }^{33}$ ile iptal edilmiştir ${ }^{34}$.

\footnotetext{
${ }^{33}$ İlgili karar için bkz. T., 27.2.2014 E. 2012/87 ve K. 2014/41.

${ }^{34}$ Anayasa Mahkemesinin iptal kararından önce, yapılacak olan tapu sicil işlemleri ve özellikle yıkım için yapılan sözleşmelerin niteliği hususunda bkz. KÜRŞAT, Zekeriya, "6306 Sayılı Afet Riski Altındaki Alanların Dönüştürülmesi Hakkında Kanunun Özel Hukuk Alanındaki Etkileri”, Kentsel Dönüşüm Hukuku (YASIN, Melikşah/ŞAHİN,
} 


\section{Yıkım Sonrası Uygulama İşlemleri}

Riskli yapıların yıkılmasından sonra, hukukî niteliği arsa haline gelen bu taşınmazların ne şekilde değerlendirileceğine karar verilmesi gerekmektedir. Kanun m. 6/I gereği, bu taşınmazların, maliklerince değerlendirilmesi esastır. Fakat aynı hükümde, tevhit ve ifraz ${ }^{35}$ işlemlerinin İdare, Bakanlı veya TOKİ tarafindan resen gerçekleştirilebileceği de belirtilmiştir. O halde, riskli alanlar bakımından düzenlenmiş olan planlara göre işlem yapılması gerekmekte olup, maliklerin bu noktada artık aksine bir karar almaları anlamlı olmayacaktır. Öğretide kimi yazarlar, riskli alanlar bakımından ilgili idare tarafından işlemler resen gerçekleştirilebileceği için, aşağıda incelenen uygulama işlemlerinin yalnızca riskli alanlar dışında yer alan riskli yapılar bakımından söz konusu olduğunu ileri sürmektedir ${ }^{36}$. Zira bu hal, Yönetmelik m. 13/V, VI hükümlerinden de anlaşılabilmektedir.

Üzerindeki yapının yıkılmasıyla arsa haline gelen taşınmazın ne şekilde değerlendirileceğine, m. 6 gereği taşınmazın maliklerince karar verilir. Maliklerin gerçekleştirebilecekleri işlemlere örnek olarak, "parsellerin tevhit edilmesine, münferit veya birleştirilerek veya imar adast bazında uygulama yapılmasina, yeniden bina yaptırılmasina, payların satışına, kat karşıllı̆̆ veya hâsılat paylaşımı ve diğer usuller ile yeniden değerlendirilmesi" gösterilmiştir. Malikler bu işlemlerden hangisini seçerlerse seçsinler, "sahip oldukları hisseleri oranında paydaşların en az 2/3 çoğunluğu ile" karar almak zorundadırlar. Esasında birden fazla malikin bulunduğu yapıların yıkılması ve akabinde değerlendirme işlemlerinin yapılması, oybirliğini gerektiren işlemlerdendir. Ancak, 6306 Sayılı Kanun bu ilkeye istisna getirmiş ve 2/3 çoğunluğu esas almıştır. Kanunun aramış olduğu 2/3 çoğunluğun, pay ve paydaş çoğunluğu mu yoksa sadece paydaş çoğunluğu mu olduğu açık değildir. Zira hükümde, "hisseleri oranında paydaşların 2/3 çoğunluğu" ifadesine yer verilmiştir.

Kanaatimizce her bir birlikte mülkiyet türü bakımından taşınmazın nasıl değerlendirileceğine ilişkin olarak yapılacak anlaşma için aranması

Cenk (ed.), İstanbul Üniversitesi S.S.ONAR İdare Hukuku ve İlimleri Araştırma ve Uygulama Merkezi Yayınları, İstanbul 2013, s. 21 vd.

${ }^{35}$ Kanunda birleşme, bölünme, taksim ifadeleri yerine gerek Türk Medeni Kanunu gerekse Tapu Sicil Tüzüğünde yer almayan tevhit ve ifraz ifadelerinin yer alması da terminolojik olarak uygun olmamıştır.

${ }^{36}$ ŞIMŞEK, s. 109; ÖZSUNAY, s. 11 vd. 
gereken çoğunluk gerek TMK'deki; gerekse KMK'deki hükümler göz önünde bulundurularak ele alınmalıdır:

Yıkımın gerçekleşmesiyle arsa haline gelen taşınmazın nasıl değerlendirileceği belirlenirken bu taşınmazın paylı mülkiyet konusu bir taşınmaz olması olasılığında TMK'nin paylı mülkiyete ilişkin $688 \mathrm{vd.}$ hükümleri ile 6306 Sayılı Kanun'un hükümlerinin örtüşmediği görülmektedir. "Birden fazla kişinin maddi olarak bölünmemiş bir şeyin tamamı üzerinde belli paylarla malik olması" olarak tanımlanan ${ }^{37}$ paylı mülkiyette bölünmeye elverişli yetki ve ödevler bakımından her bir paydaş belirli bir oranda ve tek başına maliktir. Paydaşlar, payları üzerinde tasarruf işlemlerinin büyük bir kısmını tek başına yapmakta serbesttir. Fakat paylı mülkiyet konusu eşyanın tamamı ile ilgili yönetim işlemlerinin yapılması bakımından işlemin niteliğine göre farklı çoğunluklar aranmaktadır. 6306 Sayılı Kanun m. 6'da düzenlenen, üzerindeki yapı yıkılan taşınmazın nasıl değerlendirileceği meselesi, bu işlemlerden "olağanüstü yönetim işleri" arasındadır. TMK m. 692/I'de olağanüstü yönetim işleri açıkça şöyle düzenlenmektedir: "Paylı malın özgülendiği amacın değişmesi, korumanin veya olağan şekilde kullanmanın gerekli kıldığı ölçüyü aşan yapı işlerine girişilmesi veya paylı malın tamamı üzerinde tasarruf işlemlerinin yapılması, oybirliğiyle aksi kararlaş̧ırılmış olmadıkça, bütün paydaşların kabulüne bağlıdır.". Oysa 6306 Say1lı Kanun, bu genel kurala istisna getirmekte ve "hisseleri oranında paydaşların 2/3 çoğunluğu"nu arsa haline gelen taşınmazın nasıl değerlendirileceğinin belirlenmesinde yeterli saymaktadır. Kentsel dönüşüm sürecinde karar alma süreçlerini hızlandırmak amacıyla öngörüldüğü tahmin edilen bu hükümle kast edilen kanaatimizce hem pay hem de paydaş sayısı bakımından 2/3'ün sağlanmasıdır ${ }^{38}$. Öğretide, kanunun amacindan hareketle, hükümle sadece pay çoğunluğunun

\footnotetext{
${ }^{37}$ AKİPEK, Jale/AKINTÜRK, Turgut, Eşya Hukuku, Beta Yayıncılık, İstanbul 2009, s. 389.

38 Aynı yönde, KARAKOCALI/TOKBAŞ/SENCER/KURŞUN, s. 83. Bu konudaki tartışmalar için bkz. ÖZMEN, Ethem Saba/VARDAR HAMAMCIOĞLU, Gülşah, Kat İrtifak1, Yenilenmiş 2. Bası, On İki Levha Yayınları İstanbul 2015 s. 194-198; ÖZMEN, Ethem Saba/AYDIN, Gülşah Sinem, Birlikte Mülkiyette (Paylı Mülkiyet/Elbirliği Mülkiyeti) Yapılan Kazandırıcı İşlemler ve 6036 Sayılı Kanun'a Dayalı Uygulama, Maltepe Üniversitesi Hukuk Fakültesi Dergisi, S. 1, Haziran 2015, s. 13-38. Tam metin için bkz. https://jurix.com.tr/article/5329 (E. T.: 05.10.2017).
} 
arandığ savunulmaktadır $^{39}$. Özellikle madde metnine eklenen "yapının paydaşı olup olmadıkları gözetilmeksizin" ifadesinin eklenmesiyle sadece pay çoğunluğunun arandığının vurgulandığı da ileri sürülmektedir ${ }^{40}$. Fakat kanaatimizce bu görüşe hem kanunun lafz1, hem de TMK m. 692/I'e istisna getiren ve bu yüzden dar yorumlanması gereken bir hüküm olması sebebiyle katılmaya imkân bulunmamaktadır. Ayrıca öğretide, özgüleme amacı değişmeden yapılacak değerlendirme yöntemine ilişkin anlaşmalar bakımından $2 / 3$ çoğunluğun yeterli olduğu fakat özgüleme amacının değiştiği hallerde yine TMK m. 692/II hükmü gereğince oybirliği ile karar alınmasi gerektiği, isabetli olarak savunulmaktadır ${ }^{41}$.

Genel ilkeleri TMK 701 vd. hükümlerinde düzenlenen ve sınırlı sayıda öngörülen hallerde ortaya çıkabilen elbirliği halinde mülkiyet bakımından, maliklerin belirlenmiş payları bulunmamaktadır. Elbirliği halinde mülkiyette tek bir mülkiyet hakk1 bulunur ve her bir malikin hakkı, mülkiyet hakkının konusunu oluşturan şeyin tamamına yaygındır. Bunun sonucu olarak hiçbir malikin, üzerinde tasarruf edebileceği bir "pay" bulunmamaktadır ${ }^{42}$. Kanunda ya da sözleşmede aksi açıkça belirtilmedikçe yönetim ve tasarruf işlemleri için "ortakların oybirliği" ile karar almaları gerekmektedir (TMK m. 702/2). Topluluk devam ettiği müddetçe "paylaşma" yapılamayacağı gibi "pay" üzerinde de herhangi bir tasarrufta bulunulamaz (TMK m. 702/3). Oysa 6306 Say1l Kanun m. 6.'da, yıkılan taşınmazların maliklerinin "hisseleri oranında paydaşların 2/3 çoğunluğu" ile taşınmazı ne şekilde değerlendireceklerine ilişkin karar alabilmeleri öngörülmüştür. Yıkımın gerçekleştiği ya da gerçekleşeceği taşınmazın üzerindeki mülkiyet türü ne olursa olsun $2 / 3$ çoğunluk ile karar alınmasının öngörülmesi kanaatimizce isabetsizdir. Elbirliği halinde

${ }^{39}$ Bkz. ÖZ, Turgut, Kentsel Dönüşüm Kanunu Çerçevesinde Yapı Maliklerinin Üçte İki Çoğunlukla Alacakları Kararın İçeriğinin Amaca Göre Sınırlanabilmesi, Kocaeli Üniversitesi Hukuk Fakültesi Dergisi, S.1-2, Ocak-Şubat 2016, s. 391-402. Tam metin için bkz. https://jurix.com.tr/article/7498 (E.T.: 09.10.2017).

${ }^{40}$ KOÇAKLI, Engin, Riskli alanlarda Maliklerin Uygulamasında 2/3 ile Karar Alınması ve $\mathrm{Bu}$ Alınan Kararlar Doğrultusunda İdarenin Kararları Uygulama Olanağı ve Görevi, Kocaeli Üniversitesi Hukuk Fakültesi Dergisi, S. 14, Temmuz 2016, s. 135-159. Tam metin için bkz. https://jurix.com.tr/article/7499 . (E.T.: 08.10.2017).

41 ÖZMEN/AYDIN, s. 13-38 Makalenin tam metni için bkz. https://jurix.com.tr/article/5329 , (E.T.: 05.10.2017). Bu durumda karar katılmayan 1/3 veya daha azı oluşturan azınlık

42 OĞUZMAN, Kemal/SELIÇİ, Özer/OKTAY-ÖZDEMİR, Saibe, Eşya Hukuku, 16. Tıpk1 Bası, Filiz Kitabevi, İstanbul 2013, s. 347-349; AKİPEK/AKINTÜRK, s. 410. 
mülkiyet konusu bir taşınmazın ya da taşınmazın herhangi bir orandaki payının maliklerinin 2/3'ü neye göre belirlenecektir? Zira elbirliği halinde mülkiyette bu ortaklığın tasfiyesinin sona ermesine kadar ertelenmiş farazi paylar vardır. 2/3 oranı, bu tasfiye payına göre mi belirlenecektir? Ayrıca bir taşınmaz üzerinde hem paylı mülkiyet hem de bu payların tamamı ya da bir kısmı üzerinde elbirliği halinde mülkiyet söz konusu ise yine "hisseleri oranında paydaşların 2/3 çoğunluğu" nasıl hesaplanacaktır? Bütün bu soruların cevab1 6306 Sayıl1 Kanun'un lafzından anlaşılamamaktadır. Kanaatimizce, elbirliği halinde mülkiyet konusu taşınmaz ya da taşınmaz paylarının "ortakları"nın oybirliği ile hareket etmeleri gerekmektedir. Eğer değerlendirilecek taşınmaz üzerinde sadece elbirliği halinde mülkiyet varsa "hisseleri oranında paydaşların $2 / 3$ çoğunluk"tan bahsedilemeyeceği için, oybirliği ile hareket edilmesi esastır. Bu sağlanamıyorsa, TMK m. 703 gereği "malın devri, topluluğun dağılması veya paylı mülkiyete geçilmesi" ile önce elbirliği halinde mülkiyetin sona erdirilmesi gerekir. Aksi halde gerçekleşmemiş bir tasfiyenin, farazi paylarının 2/3'ünün hesaplanması, hukukî dayanaktan yoksundur. Değerlendirilecek taşınmaz bir paylı mülkiyet konusu ise ve bu paylardan biri ya da birkaçı üzerinde de elbirliği halinde mülkiyet söz konusuysa, taşınmazın tamamının paydaşlarının hisseleri oranında 2/3'ünün nasıl hesaplanacağı tamamen belirsizdir. Kanaatimizce, paylı mülkiyetin maliklerinden elbirliği halinde malik olan ortakların sayısı kaç olursa olsun, bunlar oybirliğiyle hareket etmeli ve "tek paydaş gibi" kabul edilmelidir. Taşınmazın tamamı üzerindeki 2/3'lük pay hesaplanırken elbirliği halindeki maliklerin her birinin farazi payı değil, ortaklığın, paylı mülkiyetteki pay oranı dikkate alınmalıdır. Örneğin taşınmaz üzerinde paylı mülkiyet söz konusu olup bu taşınmazın 1/4'lük payı üzerinde miras ortaklığ olduğunu varsayalım. 1/4'ün ortaklarının farazi paylarının da birbirinden farklı oranlarda olması mümkündür. 6306 Sayılı Kanun'un m. 6 uyarınca bu taşınmazın nasıl değerlendirileceği belirlenirken miras ortaklığının payı yine $1 / 4$ olarak; fakat paydaş sayısı 1 olarak kabul edilmelidir.

Yapının üzerinde kat mülkiyeti ya da kat irtifakı mevcutsa, 6306 Sayılı Kanun m. 6/1, c. 1 uyarınca "Üzerindeki bina ylkılarak arsa haline gelen taşınmazlarda daha önce kurulmuş olan kat irtifakl veya kat mülkiyeti, ilgililerin muvafakatleri aranmaksızın Bakanlı̆̆ın talebi üzerine ilgili tapu müdürlügünce resen terkin edilerek, önceki vasfi ile 
değerlemede bulunularak veya malik ile yapılan anlaşmanın şartları tapu kütüğ̈̈nde belirtilerek malikleri adına paylar oranında tescil edilir.”. Yıkımın gerçekleşmesi ile kat mülkiyeti veya irtifakı, kanun gereği sona ermektedir. Yapının yıkılmasının kat mülkiyetini sona erdirmesi KMK m. 47 hükmüyle uyumludur. Oluşan paylı mülkiyette pay oranlarının, kat mülkiyeti rejimindeki arsa payları oranında belirlenmesi gerekir. $\mathrm{Bu}$ durumda "hisseleri oranında paydaşların $2 / 3$ çoğunluğu" hesaplanırken, paylı mülkiyet için benimsenen sonuçlar dikkate alınmalı ve hem payların hem de paydaşların $2 / 3$ çoğunluğu ile arsanın nasıl değerlendirileceğine ilişkin anlaşma yapılmalıdır.

Kat mülkiyeti veya kat irtifakı sona ermeden önce kat maliklerinin, yıkımdan sonra arsayı nasıl değerlendireceklerine ilişkin bir anlaşma yapmak istemeleri durumunda, hangi çoğunlukla karar almaları gerektiğine ilişkin 6306 Sayılı Kanun'da herhangi bir hüküm yer almamaktadır. Kanaatimizce bu durumda KMK m. 45 uyarınca oybirliği ile karar alınması gerekir, dolayısıyla $2 / 3$ çoğunluğun sağlanması bu aşamada yeterli sayılmamalıdır ${ }^{43}$.

Kanunda nitelikli çoğunluk düzenlendikten sonra, hızlı bir şekilde işlem yapılabilmesi için, bu kararların belirli sürelerde alınması ve kararların alınmamasının hukukî sonuçları düzenlenmiştir. Gerçekten de, Kanun m. 6/I'e göre, 2/3 çoğunluk ile karar alınması durumunda, karara katılmayanların payları açık artırma suretiyle öncelikle satın alan paydaşlara, paydaşlardan alıcı çıkmazsa, tespit edilen rayiç bedeli Bakanlıkça ödenerek, Hazine adına resen tescil edilir. Buna ek olarak, yıkım kararının tebliğinden itibaren 30 gün içerisinde $2 / 3$ çoğunluk ile anlaşma sağlanamaması durumunda, acele kamulaştırma yoluna başvurulur. Kanun, bu hususta, hiç anlaşma yapılamaması ile 2/3

\footnotetext{
${ }^{43}$ Aynı yönde bkz. KARAKOCALI/TOKBAŞ/SENCER/KURŞUN, s. 80. Yazarlar, kat mülkiyeti veya kat irtifakı sona ermeden önce alınan kararlarda Kat Mülkiyeti Kanunu'nun esas alınacağını ve bu kararlara karşı KMK m. 33 kapsamında dava açılabileceğini belirtmektedirler. Özellikle, 18. HD, T. 04.11.2015, E. 2015/1794 K. 2015/15821; 20. HD, T.21.10.2015, E. 2015/12215, K. 2015/9854 Kararlar için bkz. KARAKOCALI/TOKBAŞ/SENCER/KURŞUN, s. 81; GÜNAY, Meryem, Riskli Yapılarda Ortak Karar Protokolüne Karşı Açılan Davalar ve Hâkimin Müdahalesi, Kocaeli Üniversitesi Hukuk Fakültesi Dergisi, S. 14, Temmuz 2016, s. 105-133. Tam metin için bkz. https://jurix.com.tr/article/7498 (E.T.: 10.10.2017). Böyle bir karar almanın kat mülkiyeti hukuku ile ilgili değil, paylı mülkiyetle ilgili olduğu yönündeki görüş için bkz. ÖZMEN/AYDIN, s. 13-38 (Makalenin tam metni için bkz. https://jurix.com.tr/article/5329, E.T.: 05.10.2017).
} 
çoğunluğun sağlanamamasını eşit değerde tutmuş ve bu takdirde acele kamulaştırma yolunu öngörmüşken, yeterli çoğunluğun sağlandığı durumlarda, geriye kalan en fazla $1 / 3$ çoğunluk paylarının da diğer paydaşlara satışını, bunun gerçekleşmemesi durumunda da Hazine adına resen tescilini düzenlemiştir. açık artırma yoluyla satışa, yalnızca diğer paydaşlar katılabildiği için burada özel artırma yoluyla satış türü söz konusudur $^{44}$.Kanun $\mathrm{m}$. 6/I'de, rayiç bedele nasıl itiraz edileceği, paydaşlar arasında satışın ne şekilde gerçekleştirileceğine yer verilmemiştir. Yönetmelik m. 15/A'/I'de "Rayiç değer, maliklerce Sermaye Piyasası Kuruluna kayıtlı olarak faaliyet gösteren lisanslı değerleme kuruluşlarına tespit ettirilmişs olan taşınmazın değeri de gözetilerek Bedel Tespiti Komisyonunca belirlenir." hükmü yer almakta olup, rayiç bedel belirlemesinin daha önce değerleme kuruluşuna tespit yaptırılmış olsa bile komisyon tarafindan belirleneceği düzenlenmiştir. Maddede açık artırmaya ilişkin son derece ayrıntılı düzenlemelere yer verilmişken bedele itiraza ilişkin düzenleme bulunmamaktadır. Kanaatimizce, Yönetmelikte bedele itiraza ilişkin düzenlemeler yapılması yerinde olacaktır. Azınlığın paylarının satılmasında, azınlıktaki paydaşların çoğunluk kararına katılmaya yönelik iradelerinin sonradan oluşması ihtimaline karşı da düzenleme yapılmıştır. Yönetmelik m. 15/A/XI, "Satış işlemi tamamlanip komisyonca karara bağlanmadan evvel, üçte iki çoğunluk ile alınan karara katılmayan maliklerin, üçte iki çoğunluk ile alınan kararı kabul etmeleri ve üçte iki çoğunluk ile alınan karar doğrultusunda yapılan sözleşmeyi ve yapılacak uygulamanın gerektirdiği diğer belgeleri imzalayacakların beyan etmeleri halinde Satış Komisyonunca kendilerine süre verilir." hükmüne yer verilmiştir. Buna göre, açık artırma yoluyla satışta, satılan hisselerin mülkiyetin geçişi bakımından satışın tamamlanması esas alınmamıştır. Komisyon, satışı karara bağlayana kadar, azınlık hisselerinin malikleri çoğunluk kararına katıldıklarını belirterek ve söz konusu belgeleri imzalayarak satışın önüne geçebilmektedir.

\footnotetext{
${ }^{44}$ Artırma yoluyla satış, cebri satış ve isteğe bağlı satış şeklinde ikiye ayrılır. İsteğe bağlı artırma yoluyla satışta satıcı, ihaleye girecek olan kişileri belirlemekte ve sınırlamaktaysa, isteğe bağlı özel artırma yoluyla satış söz konusu olmaktadır. 6303 Sayılı Kanun m. 6'da bu kategorilerden hiçbirine girmeyen devlet organlarınca gerçekleştirilen fakat herkese açık olmayan bir ihale usulü uygulanmaktadır.
} 


\section{6306 SAYILI KANUN KAPSAMINDA KENTSEL DÖNÜŞÜM SÜRECININ TAPU SİCIL IŞLEMLERİ BAKIMINDAN DEĞERLENDIRILMESI}

6306 Sayılı Kanun'da tescil, şerh, beyan, terkin şeklinde düzenlenen tapu sicil işlemlerinin ${ }^{45^{\circ}}$ bu Kanun'un uygulanması bakımından yaratabileceği sorunlar ele alınmalıdır. Her bir tapu sicil işlemi bakımından ortaya çıkabilecek sorunlar aşağıda ayrı ayrı incelenmektedir.

\section{A. Tescil}

Dar anlamda ayni hakların tapu kütüğüne yazılmasını ifade eden tescil işlemine, 6306 Sayılı Kanun'un farklı hükümlerinde yer verilmiştir.

-İlk olarak, Kanun'un m. 3/IV hükmünde ${ }^{46}$, tescil dışı alanların, Hazine adına tescil edilerek, Bakanlık, TOKİ veya İdareye bedelsiz devredilebileceği düzenlenmiştir ${ }^{47}$. Öncelikle incelenmesi gereken, tescil dışı alanların kapsamına hangi taşınmazların girdiğidir. Tapu Sicil Tüzüğü’nün m. 8/II'de, “Özel mülkiyete tâbi olmayan ve kamunun yararlanmasina ayrılan taşınmazlar, bunlara ilişskin tescili gerekli bir aynî hakkın kurulması söz konusu olmadıkça kütüge kaydolunmaz." hükmüne yer verilmiştir. Hükmün içeriğini kamu malları (devlet malları) oluşturmaktadır. Kamu malları, kamunun ortak kullanımına veya hizmetine tahsis edilen mallar ve sahipsiz yerlerdir ${ }^{48}$. Bu taşınmazlar (dağlar, tepeler, yararı kamuya ait mallar vb.) ise, TMK m. 715 gereği devletin hüküm ve tasarrufu altındadır. Kamu malı niteliğindeki

\footnotetext{
${ }^{45}$ ÜNAL, Mehmet./BAŞPINAR, Veysel, Şekli Eşya Hukuku, Savaş Yayınevi, Ankara 2016, s. 308 vd. (ÜNAL/BAŞPINAR, Eşya); AYAN, Mehmet., Eşya Hukuku I, Zilyetlik ve Tapu Sicili, 13. Baskı, Seçkin Yayıncılık, Ankara 2016, s. 266; SİRMEN, Lale, Eşya Hukuku,Yetkin Yayınları, Ankara 2013, s. 195 vd.; ESENER, Turhan/GÜVEN, Kudret, Eşya Hukuku, 5. Bask1, Yetkin Yayınları, Ankara 2012, s. 125 vd;; AKIPEK/AKINTÜRK, s. 282 vd.; OĞUZMAN/SELIÇI/OKTAY-ÖZDEMİR, s. 201 vd.

46 "Bu Kanuna göre uygulamada bulunulan alanlarda yer alan tescil dışı alanlar, tapuda Hazine adına tescil edildikten sonra Bakanlığa tahsis edilerek tasarrufuna bırakılır veya Bakanlı̆̆ın talebi üzerine TOKI'ye ve İdareye bedelsiz olarak devredilebilir."

${ }^{47}$ Bedelsiz terk ve devirin hukukî niteliği noktasında ayrıntılı bilgi için bkz. YILDIRIM, Ramazan, "İdâreye Taşınmaz Mal Kazandıran Bedelsiz Terk, Devir ve Temlikler", KTO Karatay Üniversitesi Hukuk Fakültesi Dergisi, C. 1, S. 2, Temmuz 2016, Sayfa: 13-22 (Tam metin için bkz. https://www.jurix.com.tr/article/5404 E.T.: 07.10.2017).

${ }^{48}$ EREN, Fikret/BAŞPINAR, Veysel, Toprak Hukuku, 4. Bask1, Yetkin Yayınları, Ankara 2014, s. 336. Ayrıca kamu mallarına ilişkin 3402 Sayılı Kadastro Kanunu'nun 16. maddesi de düzenlemeler içermektedir.
} 
taşınmazların ilgili kurum ve kuruluşların talebiyle bedelsiz olarak devredilir ve tescil edilir ${ }^{49}$. Kanun doğrudan bu alanlara ilişkin tescil ve tahsis yetkilerini ilgili kurum ve kuruluşlara tanımıştır ${ }^{50}$.

-Tescil işleminin düzenlendiği hükümlerden bir diğeri ise, 6306 Sayılı Kanun'un 6. maddesidir. Hükümde, yıkılan yapıların, önceki durumlarına göre tapuda malikleri adına tescil edileceğinden bahsedilmektedir. Tescil, ilgililerin muvafakati aranmaksızın, Bakanlığın talebiyle gerçekleşmektedir. Diğer bir deyişle, Bakanlığın talebi, arsa haline gelen taşınmazın, malikleri adına tescili için yeterli olmaktadır. Hükümde, kat mülkiyeti veya irtifakı bulunan bir yapının yıkılmasından sonra paylı mülkiyet esasına dayalı olarak malikler adına payları oranında tescil yapılacağı öngörülmüştür. Yukarıda da açıklandığı üzere ${ }^{51}$ Kanun'un sadece tek bir mülkiyet türünü dikkate alarak düzenleme yapması yerinde değildir. Zira kat mülkiyeti veya irtifakının olmadığ paylı, müstakil, elbirliği halinde mülkiyet hallerinde arsa üzerinde bulunan yapının yıkılmasıyla hak sahiplerinin lehine gerçekleşen tescillerde herhangi bir değişiklik gerçekleşemeyecektir. Kat mülkiyeti konusu taşınmazlarda, 634 Sayılı Kat Mülkiyeti Kanunu m. 48/II hükmünde de yapının tamamen veya kismen harap olması durumunda arsa payları oranında tescilin yapılacağı düzenlenmiştir. 6306 Sayılı Kanun da aynı durumu düzenlemekle birlikte, KMK hükmünde, tapuya kat mülkiyeti ilişkisinin bildirilmesi gerekirken; 6306 Sayılı Kanun'da terkin ve tescil resen gerçekleştirilmektedir. Tescilin gerçekleştirilmesi ve malikler tarafından binanın ne şekilde değerlendirileceğine karar verilmesi için 6306 Sayılı Kanun 2/3 çoğunluk aramıştır. Bu oranın her bir mülkiyet türü bakımından hesabı yukarıda ${ }^{52}$ açıklanmış olmakta birlikte, burada ortaya

${ }^{49} 6306$ Sayılı Kanun'un m. 3/V hükmünde ise, söz konusu alanların tahsis ve devir tarihinden itibaren üç yıl içerisinde maksada uygun kullanılmaması durumunda bedelsiz olarak ve resen Hazine veya önceki kamu idaresine devrinin mümkün olduğu düzenlenmiştir. Kanaatimizce, bu hüküm ve Kanun'un m.4/II'de yer alan hükmü birlikte değerlendirildiğinde, tescil ve devri sağlanan taşınmazlar üzerinde gerçek anlamda özel mülkiyetin oluştuğunu ileri sürmek mümkün gözükmemektedir.

${ }^{50}$ Söz konusu taşınmazlara ilişkin devletin sahip olduğu "hüküm ve tasarrufu altında olmak" ifadesinin gerçek anlamda bir mülkiyet hakkı doğurup doğurmadığı, doğurmakta ise de idari-özel mülkiyet olup olmaması meselesi öğretide tartışmalıdır. Tartışmalar için bkz. ÜNAL, Mehmet/BAŞPINAR, Veysel, Orman Hukuku, 4. Baskı, Savaş Yayınevi, Ankara 2017, s. 65 vd. (ÜNAL/BAŞPINAR, Orman).

${ }^{51}$ Bkz. yukarıda IV, C.

${ }^{52}$ Bkz. IV, C. 
çıkabilecek hukukî sorunlardan birisi de, maliklerin yıkım öncesi sahip oldukları taşınmazlar ile yıkımdan sonra tescil edilen arsa pay oranlarında ortaya çıkabilecek uyumsuzluktur. Zira kat mülkiyetinin kurulduğu aşamada bağımsız bölümlere tahsis edilen arsa payları fiili durumu yansıtmayabilir. Böyle bir durumda malikler tarafından arsa payına ilişkin tapudaki kaydın düzeltilmesi için bağımsız bölüm maliki veya mirasçılarının dava açması gerekmektedir ${ }^{53}$. Düzeltme davasının açılmasında herhangi bir hak düşürücü sürenin bulunmadığ1 ve yap1 üzerinde kat mülkiyeti veya irtifakı ilişkisi devam ettiği sürece, davanın açılabileceği Yargıtay kararlarında belirtilmektedir ${ }^{54}$. Davaya ilişkin 6306 Sayılı Kanun'da herhangi bir hüküm bulunmamakla birlikte, KMK m. 3 gereği söz konusu dava herhangi bir süreye tabi olmadan açılabilir. Ancak, davanın yıkım gerçekleşmeden önce veya sonra açılmasına göre de bir ayrım yapmak gerekir. Kural olarak yıkımdan önce düzeltme davasının açılması daha yerinde olup, özellikle bağımsız bölümlerin var

\footnotetext{
${ }^{53}$ ŞİMŞEK, s. 115.

54 18. HD, T. 03.03.2008, E. 2007/9977 K. 2008/2872. Ayrıca bkz. ALPÖĞÜNÇ, Erkan, “Arsa Payı Kavramı, Önemi, Hesaplanması, Düzeltme Davası", TBBD S. 89 Y. 2010, Ankara 2010, s. 502 vd.; ÇAĞATAY, Saliha, "6306 Sayılı Afet Riski Altındaki Alanların Dönüştürülmesi Hakkında Kanun Uyarınca Kat Mülkiyetinin Sona Ermesi ve Sonuçları”, Kocaeli Üniversitesi Hukuk Fakültesi Dergisi, C. 5, S. 9, Ocak 2014, s. 115138 (Tam metin için bkz. https://www.jurix.com.tr/article/4395 E.T.:07.10.2017). Yargıtay'ın oldukça yeni tarihli bir kararında ise, "Kanun gereğince; arsa payı düzenlemesinin yeniden yapılabilmesinin ilk şartı, arsa paylarının bağımsız bölümlerin değerleriyle oransız olarak belirlenmiş olmasıdır. Bu hususa dayalı istemlerde mahkeme tüm kanıtları değerlendirerek bağımsız bölümün değeri ile bölüme özgülenen arsa payını karşılaştırıp denklik sağlamaya çalışmalıdır. Söz konusu işlem yapılırken de bağımsız bölümlerin cinsi, bulunduğu kat, alanı, ısınma sistemi, aydınlanması, mimari kullanımı ve konumu, cephesi ve manzarası gibi hususlar değerlendirme için esas alınır. Değerlendirmeye esas alinacak tarihten sonraki imar durumu ile cins ve manzara değişiklikleri, bakım ve onarım çalışmaları nedenleriyle meydana gelen değer artı̧ ve eksilmeleri dikkate alınmaz." ifadesine yer verilmiştir (Y. 20. HD. T. 27.3.2017, E. 2017/4756 K. 2017/2449, KBİBB, E.T.: 09.10.2017). Söz konusu kararda ve benzer başkaca kararlarda da yer alan, "tapu sicilinde kayttlı arsa paylarında düzeltilmesi gereken bir yanlışlık olduğu konusunda mahkemece herhangi bir değerlendirme ve gerekçe içermeyen soyut ve genel ifadeli bilirkişi raporu esas alınarak hüküm kurulması doğru görülmemiştir." gerekçesine dayanılarak davacının talebi reddedilmiştir. Diğer kararlar için bkz. Y.18 HD. T. 27.6.2017, E. 2015/9964, K. 2016/10111; Orantısızlı̆̆1 ileri süren malikin daha önceden tescil edilen paya rızasının olması halinde iyiniyetli olamayacağı noktasında Y. 18 HD, T. 6.6.2016, E. 2016/5303, K. 2016/9069; 18. HD, T. 19.09.2002, E. 2002/7706, K. 2002/8323, KBİBB, E.T.: 09.10.2017).
} 
olan durumlarına göre arsa paylarının hesaplanması mümkün olur. Yıkımdan sonra düzeltme davasının açılması halinde ise, kat mülkiyetinin yıkımla beraber sona ereceğini ve dava açılamayacağını ileri sürmek hakkaniyete uygun değildir. $\mathrm{Bu}$ yüzden öğretide haklı olarak ileri sürüldüğü üzere, 6306 Say1lı Kanun m. 6/I'de yer alan "önceki vasfi ile değerlemede bulunularak" ifadesi kapsamında, malikler dava açabilir ${ }^{55}$. Diğer bir deyişle, mahkeme bağımsız bölümlerin değerleri ile tapuda resen gerçekleştirilmiş paylar arasındaki oranı dikkate alır ${ }^{56}$.

-6306 Sayılı Kanun'da tescil işlemine yer verilen hükümlerden bir diğeri de m. 6/I/c. 7'dir. Hükümde, 2/3 çoğunluk ile maliklerin karar alması ve bu çoğunluğa katılmayanların paylarının diğer paydaşlara satışının gerçekleştirilemediği durumlarda, rayiç bedelin Bakanlıkça ödenmesi koşuluyla devrin Hazineye gerçekleştirileceği ve tescilin de resen yapılacağı öngörülmüştür. Bu hükümde kanundan kaynaklanan bir tescile imkân tanınmıştır. Tescilin şartları bakımından, tescilin sebebi Kanun hükmü olup, tescil talebinde bulunması gereken, hak sahibinin tescil talebinde bulunması genel kuralının aksine, Hazine olarak belirlenmiştir ${ }^{57}$.

-Kanun'un 6. maddesinin ikinci fikrasında da yine tescil ifadesine yer verilmiş ve $2 / 3$ çoğunluğun sağlanamaması halinde, acele kamulaştırma yoluna gidileceği düzenlenmiştir. Kamulaştırmanın malikler ile anlaşma yoluyla sağlanması durumunda, tapu sicil işlemleri bakımından, ferağ ve muvafakate ilişkin, ilgililer ve idare arasında tutanak düzenleneceği de belirtilmiştir. Esasında anlaşma yoluyla kamulaştırma gerçekleştiği takdirde, belirtilen tutanağın da Tapu Müdürlüğüne gönderilmesiyle resen tescil yoluna gidilebilir. Kamulaştırmanın, TMK m. 705 gereği, taşınmaz mülkiyetinin tescilsiz kazanım hallerinden olması sebebiyle, altıncı maddede yer alan resen tescil, açıklayıcı nitelikte olup, mülkiyet devri, tutanağın düzenlenmesiyle birlikte gerçekleşir (Kamulaştırma Kanunu m. 8/V).

\footnotetext{
${ }^{55}$ KÜRŞAT, s. 40-41.

${ }^{56}$ Bağımsız bölümlerin değeri tespit edilirken yalnızca yüzölçümünün esas alınmasının isabetsiz olduğu hususunda Yargitay kararı için bkz. 18. HD, 17.02.2009 T, ;E. 2008/13132, K. 2009/1268, KBIBBB, E.T.: 09.10.2017.

${ }^{57}$ Tescilin şartları hakkında bkz. ÜNAL/BAŞPINAR, Eşya, s.337 vd.; ESENER/GÜVEN, s. 126 vd.; AKİPEK/AKINTÜRK, s. 287 vd.; SİRMEN, s. 196 vd.; OĞUZMAN/SELIÇİ/OKTAY-ÖZDEMİR, s. 202 vd.
} 
-Tescil işlemine yer verilen hükümlerden bir diğeri ise, m.6/XI hükmüdür ${ }^{58}$. Anılan hükümde, Kanun kapsamında Bakanlığa tahsis edilen veya TOKİ ya da idareye devredilen taşınmazların üzerinde yeni oluşan taşınmazların, bu kurum veya kuruluş ile anlaşma sağlayan gerçek ya da tüzel kişiler adına tescilinin yapılabileceği düzenlenmiştir. Bu hükümle, maddenin on ikinci fikrası birlikte değerlendirildiğinde, Kanun ile Bakanlık, TOKİ ve İdareye üçüncü kişiler ile anlaşma yapabilmek konusunda takdir yetkisi tanınmıştır. Bakanlığın takdir yetkisini kullanabileceği iki durum bulunmaktadır. Bunlardan ilki taşınmazların Bakanlık talebiyle ilgili kurumlara devrine; ikincisi ise, Bakanlıkça hangi iş ve işlemlerin hangi kurum tarafından gerçekleştirileceğine ilişkindir. $\mathrm{Bu}$ çalışma bakımından önem arz eden konu, anlaşma sağlanan kişiler adına tapuda tescil için yetkili kurumun talebinin bulunması gerektiğidir ki bu eşya hukuku prensiplerinden tescilin taşınmazın maliki tarafından talep edilmesi ilkesine uygundur.

- Kanun'da tescile ilişkin düzenlemelerden bir tanesi de m.7/IX'da yer alan, harç ve vergiler bakımından getirilmiş olan istisnalardır. Hükümde, devir ve tesciller ile ilgili işlemler bakımından noter, tapu, belediyeler tarafindan alınan harçlar ve damga, veraset intikal vergileri ve diğer ücretlerin müstesna olduğuna yer verilmiştir. Hükümde belirtilen "tescil ile ilgili uygulamalar" ifadesi, geniş bir yorumu gerektirmektedir. Buna göre, tapuda gerçekleştirilecek tüm tapu sicil işlemleri bakımından anılan bedellerin alınmayacağı sonucuna ulaşılabilir. 6306 Sayılı Kanun'da öngörülen her tür tapu sicil işlemi, noter, tapu ve belediyeden alınan harçlardan, veraset ve intikal vergisinden, döner sermaye ücretleri ve diğer ücretlerden, banka ve sigorta muameleleri vergisinden müstesna sayılmaktadır. Dolayısıyla işlemi yapan hangi kişi ya da kurum olursa

$58 \mathrm{Bu}$ çalışmanın sınırları dışında olmakla beraber, idari kurumlara devredilmiş taşınmazların, üçüncü kişilere sadece anlaşma yoluyla devrinin gerçekleştirilebilmesi, ilk bakışta soru işareti uyandırır. Zira belirtilen taşınmazlar, tescile konu olmayan ya da diğer kamu kurumlarına ait olan veya kamulaştırma yoluyla söz konusu idari kurumlara geçen taşınmazlar olup, tahsis veya devir yapılan İdare tarafindan meydana gelen yeni taşınmazların hangi usulle devredilebileceği düzenlenmemiştir. Bu sebeple hükmün iptali için Anayasa Mahkemesi'ne başvurulmuş ve Yüksek Mahkeme tarafindan hükmün kanun koyucunun takdir yetkisinin kapsamında olduğu ve bu nedenle anayasaya aykırı olmadığına karar verilmiştir. Karar için bkz. http://www.resmigazete.gov.tr/main.aspx?home=http://www.resmigazete.gov.tr/eskiler/2 014/07/20140726.htm\&main=http://www.resmigazete.gov.tr/eskiler/2014/07/20140726. htm, E.T.: 07.10.2017 
olsun bu kişiler Kanun kapsamında gerçekleşen hiçbir tescil işlemi için, tapu sicil harç, vergi ve masraflarını ödemek zorunda kalmayacaktır.

\section{B. Şerh}

Şerh işlemi, en genel ifadeyle hukuk düzeninin sınırlı şekilde öngördüğü durumların tapu kütüğüne işlenmesi 59 olarak tanımlanmaktadır. Şerh işlemiyle belirli hakların üçüncü kişilere karşı ileri sürülme imkânı yaratılmış olur. 6306 Sayılı Kanun'da da, şerh işlemine m. 6/I'de yer verilmiş olup, hüküm uyarınca "Bu taşınmazların sicilinde bulunan ayni ve şahsi haklar ile temlik hakkını kısitlayan veya yasaklayan her türlü şerh, hisseler üzerinde devam eder.". Madde metniyle, paylar üzerinde devam edeceği öngörülen şerhlerin sadece, kişisel hakların ve tasarruf yetkisi kısıtlamalarının şerhi mi olduğu, yoksa geçici tescil şerhinin maddenin kapsamına girip girmediği tartışmaya açıktır. 6306 Sayılı Kanun uyarınca yıkım işleminin ardından taşınmazın tapudaki sayfasında yer alan bütün şerhlerin "paylar üzerinde devam etmesi"nin anlamı ve sonuçları, şerh türleri bakımından ayrı ayrı değerlendirilmelidir. Türk hukukunda pek çok kanunda şerh işlemine yer verilmektedir. Bu şerhler "kişisel hakların şerhi, tasarruf yetkisi kısıtlaması şerhi ve geçici tescil şerhi" olmak üzere başlıca üç grupta incelenmektedir. Her bir grup şerhin amacı ve fonksiyonu farklılık arz etmektedir:

Kişisel hakların şerhinin başlıca amacı, bu hakların, taşınmaz üzerinde sonradan hak kazananlara karşı da ileri sürülebilmesini sağlamaktır. Bu bakımdan 6306 Sayılı Kanun gereği arsa haline gelen taşınmazın sayfasında, yıkımdan önce yer alan şerhlerin, yıkımdan sonra paylar üzerinde devam etmesine ilişkin düzenlemeyle, kişisel hak sahiplerinin menfaatlerinin korunmasının amaçlandığı tahmin edilmektedir. Fakat çoğu kez paylar üzerinde bu şerhlerin devam etmesi, kişisel hak sahiplerinin menfaatlerinin kentsel dönüşüm ile büyük ölçüde boşa çıkmasının önüne geçemeyecektir. Çünkü yıkımdan sonra pay üzerindeki kişisel hakkın taşınmazın belirli şekilde değerlendirilmesi sürecinin ardından kullanılabilir bir hak olup olmayacağı belirsizdir. Örneğin yıkılmadan önce işyeri olan bir taşınmaz üzerindeki kira hakkına ilişkin şerh, paydaşlarca değerlendirmenin konut şeklinde gerçekleşmesi halinde ne anlama gelecektir? Başka bir hukukî sorun da özellikle arsa payı karşılığı inşaat, alım, önalım, gerialım ya da taşınmaz satış vaadi

${ }^{59}$ AKİPEK/AKINTÜRK, s. 313; OĞUZMAN/SELIÇĊ/OKTAY-ÖZDEMİR, s. 216. 
sözleşmelerinden doğan haklarını şerh ettiren kişilerin 6306 Sayılı Kanun m. 6 uyarınca $2 / 3$ çoğunluğa katılmayan paydaşların paylarının açık artırma yoluyla satışına karar verilmesi halinde ortaya çıkabilecektir. Konuya ilişkin daha detaylı bir hükmün öngörüldüğü Yönetmelik'in 15 ve 15/A maddelerinde açık artırma usulü ile satış düzenlenmiştir. Yönetmeliğin m. 15/A/VI/c.1 uyarınca "Açık artırmaya en az üçte iki çoğunluk ile anlaşan paydaşlar dışında herhangi biri katılamaz.". Kanaatimizce açık artırmaya paylar üzerinde şerh edilmiş olan özellikle arsa payı karşılığı inşaat, alım, önalım, gerialım ya da taşınmaz satış vaadi sözleşmelerinden doğan hakların sahiplerinin de katılabileceğinin öngörülmesi normun amacına, mevcut düzenlemeden daha çok hizmet ederdi. Zira Kanun'un m. 6/I'de. "Açık artırma ile satışı yapılacak payların üzerindeki ipotek, ihtiyati haciz, haciz ve intifa hakkl gibi haklar, satış sonrasında satı̧̧ bedeli üzerinde devam eder. Satış işlemi sonrasında tapu kaydındaki haklar ve şerhler Bakanlığın talebi üzerine tapu müdürlügünce resen terkin edilir." hükmü ile kişisel hakkını şerh ettiren üçüncü kişilerin kişisel haklarını evvelce kuvvetlendirmiş olmalarının, şerhin satışının ardından Bakanlık tarafından resen terkin edilecek olması sebebiyle bir önemi ve anlamı kalmamaktadır Açık artırmaya bu kişilerin de katılabilmesine ilişkin olarak önerdiğimiz çözüm, bir nebze de olsa kişisel hak sahiplerinin olası menfaat kayıplarının önüne geçmeye yarayabilir. Kanaatimizce Kanun'a ve Yönetmelik'e konuya ilişkin açık hükümler eklenebilir.

Tasarruf yetkisinin kısıtlanmasına ilişkin şerhler, adından da anlaşılacağı üzere, taşınmaz malikinin taşınmazı üzerinde tasarruf yetkisinin daraltılması ya da tamamen ortadan kaldırılması amacını taşır ${ }^{60}$. Çekişmeli kişisel haklar; haciz, iflas kararı ya da konkordato ile verilen süre; kanunen şerh verilmesi öngörülen işlemler tapuya şerh edilmekle, taşınmaz üzerinde sonradan hak kazananlara karşı ileri sürülebilmektedir (TMK m. 1010). 6306 Sayılı Kanun'un m. 6/I uyarınca “temlik hakkını kisitlayan veya yasaklayan her türlü şerh" in paylar üzerinde devam edeceği belirtilmiştir. Fakat bu pay, değerlendirme anlaşmasına katılmayan $1 / 3$ 'lük dilimde yer alan bir paysa ve pay açık artırma ile

${ }^{60}$ ÜNAL/BAŞPINAR, Eşya, s. 358 vd.; NOMER, Haluk Nami /ERGÜNE, Serkan, Eşya Hukuku Zilyetlik ve Tapu Sicili, 4. Gözden Geçirilmiş 4. Bası, On İki Levha Yayınları, İstanbul 2017, s. 142. 
satılmışsa, türü bakımından herhangi bir ayrım gözetilmeksizin şerhlerin resen terkin edileceği hükme bağlanmıştır.

TMK m. 1011'de düzenlenen geçici tescil şerhi ile çekişmeli bir ayni hakkın güvence altına alınmak istenmesi ya da tescil için gerekli belgelerin eksik olması halinde bunların tamamlanması amaçlanmaktadır ${ }^{61}$. Bu şerhlerin yıkımın ardından pay üzerinde devam etmemesi, hak iddiası taşıyan üçüncü kişiler bakımından hak kayıplarına neden olabilir. $\mathrm{Bu}$ nedenle bu şerhlerin de, 6306 Sayılı Kanun m. 6 metninden anlaşılamamakla birlikte pay üzerinde devam etmesi gerektiği kabul edilmelidir. Ancak bu şerhler değerlendirme anlaşmasına katılmayan 1/3'lük paylara ilişkinse, açık artırma sonucunda bu şerhler de resen terkin edilir.

\section{Beyan}

Beyan, TMK ve Tapu Sicil Tüzüğünde tanımlanmayan fakat konusu olan işlemlerden, anlamı ve kapsamı anlaşılabilen bir tapu sicil işlemidir. Hatta birçok düzenlemede, niteliği tartışmalı olmakla birlikte beyan olarak öngörülmüş tapu sicil işlemleri bulunmaktadır ${ }^{62}$. Beyan, tescil ve terkinin aksine tasarruf işlemi olmayıp, bir taşınmaza ilişkin fiili veya hukukî durumların açıklanması amacını taşır ve bu durumların üçüncü kişilere de ileri sürülmesini sağlar ${ }^{63}$. Dolayısıyla, taşınmaz üzerinde hak kazanan kişilere beyanlar kısmında yapılan belirtmeler ileri sürülebiliir ${ }^{64}$. Ancak, beyanlar açıklayıcı nitelikte olup, doğrudan ayni haklara ilişkin herhangi bir etki yaratmaz ${ }^{65}$. Buna ek olarak, tapu siciline güvenin korunması ilkesi beyanlarda uygulanmaz ${ }^{66}$.

6306 Sayılı Kanun'un m. 3/II'de, yapıların riskli olduğunun tapuda beyanlar hanesinde belirtileceği ve taşınmaza ilişkin ayni ve şahsi hak

${ }^{61}$ TMK m. 1011'de açıkça sayılmış olmamakla birlikte TMK m. 893-895 hükümlerindeki alt yüklenici ve zanaatkarların kanuni rehin istemelerine ilişkin haklarının şerhi de geçici tescil şerhi olarak değerlendirilmektedir. Bkz. AYAN, C.I, 410.

${ }^{62}$ ERGÜL, Iş1l, Tapu Sicilinde Beyanlar, Galatasaray Üniversitesi Sosyal Bilimler Enstitüsü Özel Hukuk Anabilim Dalı Yayımlanmamış Yüksek Lisans Tezi, İstanbul 2011, s. 54.

${ }^{63}$ AYAN, s. 422 vd.; SİRMEN, s. 241; OĞUZMAN/SELİÇİ/OKTAY-ÖZDEMİR, s. 233.

${ }^{64}$ ERGÜL, s. 61. Ancak ögrretide, beyanların hüküm ve sonuçlarının her hale göre değiştiği ve bu sebeple belirli bir kural koymanın mümkün olmadığı ileri sürülmektedir. Bkz. ÜNAL/BAŞPINAR, Eşya, s. 412; KÜRŞAT, s. 31.

${ }^{65}$ ÜNAL/BAŞPINAR, Eşya, s. 333; OĞUZMAN/SELIÇ்̇/OKTAY ÖZDEMİR, s. 262.

${ }^{66}$ ERGÜL, s. 61 ve özellikle dn. 243 'te sayılan yazarlar. 
sahiplerine bilgi verileceği düzenlenmiştir. 6306 Sayılı Kanun m. 3/II hükmünün 2. cümlesinde yer alan, belirtme ifadesi öğretide bir kısım yazarlarca eleştirilmektedir ${ }^{67}$. Hükmün ilk cümlesinde beyan ifadesine yer verilmişken, ardından belirtme ifadesinin kullanılması ve Tapu Sicil Tüzüğü'nde de beyan ifadesinin benimsenmiş olması sebebiyle, hükmün özensiz bir şekilde kaleme alındığı ileri sürülmektedir. Buna göre, tespit raporuna ilişkin bildirimin Bakanlık veya İdare tarafindan gerçekleştirileceği ve tapu müdürlüğünün de bu bildirim üzerine beyanlar hanesinde belirtme yapacağı düzenlenmiştir. Kanunla getirilmiş olan yeni bir beyan işlemi bulunmaktadır. 6306 Sayılı Kanun'da yer alan beyan işlemiyle tespit kararının varlığının açıklandığı ve bu konuda iyiniyet iddialarının ortadan kaldırıldığ 1 ileri sürülmektedir ${ }^{68}$. Diğer bir deyişle, sonradan ayni hak kazananların, yapının riskli olduğunu bilmediklerini ileri sürmelerine imkân kalmaz. Örneğin, taşınmazın riskli yapı olduğuna ilişkin beyanlar hanesine belirtme yapılmasından sonra, bu taşınmazı satın alan iyiniyetli kişiler yıkıma karşı herhangi bir itirazda bulunamaz.

Kanun'un beyan işleminin, taşınmaz üzerindeki kişisel hak sahiplerine etkisi de değerlendirilmelidir. Öğretide, kiracının, taşınmazı riskli yapıya ilişkin beyanı bilmeden kiralaması halinde kiraya verenin ayıptan doğan sorumluluğuna ilişkin hükümlere başvurabileceği ileri sürülür ${ }^{69}$. Kiraya verenin ayıptan doğan sorumluluğu, yapının riskinin kendisinden kaynaklanıp kaynaklanmamasına veya yıkımın gerçekleşmesine bağlı değildir ${ }^{70}$. Ancak, yapının kira sözleşmesinin kurulmasından sonra riskli hale gelmesi ihtimalinde, kiraya verenin ayıptan doğan sorumluluğuna başvurulabilir fakat kiraya verene kusur yüklenemeyeceği için kendisinden tazminat talebinde bulunulamaz.

\section{Terkin}

Terkin işlemi, 6306 Sayılı Kanun'un m. 6/I, II'de yer almaktadır. İlk fikrada yer alan hükümde, taşınmazların yıkılmasından sonra kat mülkiyeti veya kat irtifakının, maliklerinin muvafakatine gerek bulunmaksızın resen terkin edileceği düzenlenmiştir. Böylece, fiili durum hukukî durumla eşleştirilmektedir. Zira binanın yıkılması ile kat mülkiyeti

${ }^{67}$ ÖZSUNAY, s. 18 dn. 16.

${ }^{68}$ KÜRŞAT, s. 31.

${ }^{69}$ KÜRŞAT, s. 32.

${ }^{70}$ Kiraya verenin kiracıyla, yapının riskli olduğunu bile bile sözleşme yapması halinde, kusurlu olduğu kabul edilir ve bu nedenle culpa in contrahendo sorumluluğu uyarınca kendisinden tazminat talep edilebileceği ileri sürülmektedir. Bkz. KÜRŞAT, s. 33. 
kendiliğinden sona erdiği için var olan kayıtların artık hukukî bir hükmü bulunmamaktadır. Bu yüzden kanun koyucu resen terkin için Bakanlığın talebini yeterli görmüştür.

Maddenin ikinci fikrası uyarınca, taşınmazların yıkımından sonra $2 / 3$ çoğunluk ile karar alınamaması ve kamulaştırma yoluna gidilmesi halinde, maliklerle yapılan uzlaşma tutanağında terkine ilişkin maliklerin feragat ve muvafakatlerinin bulunması gerekmektedir. Yapılan düzenlemede, Bakanlık, TOKİ veya İdareye geçen taşınmaz payı üzerinde her tür tasarruf işleminin gerçekleştirilebilmesi için hem tescil hem de terkin ifadesine yer verilmiştir.

\section{SONUÇ}

6306 Sayılı Kanun'un genel felsefesinin, kişilerin yaşam hakkının korunabilmesi ve yaşam alanlarının dönüştürülmesi olduğu söylenebilir. Bununla birlikte, Kanun'da dönüşüm için gerçekleştirilebilecek olan uygulamalar, mülkiyet hakkının ihlaline de yol açmaktadır. Bu kapsamda, özellikle Anayasa Mahkemesi kararı ile iptal edilen hükümler yerinde olmakla birlikte, halen Kanun'da, dönüşüm sürecini hızlı tutmak adına idareye verilmiş geniş yetkiler bulunmaktadır. Bununla birlikte, tapu sicil işlemleri bakımından tamamen kanuni düzenlemelere dayanılarak işlem yapılması ise, eşya hukukundaki ilkelerin tersine bir durum oluşturmaktadır. Ayrıca, anılan Kanun ve uygulama yönetmeliği arasında normlar hiyerarşisi ve tapu sicil işlemleri için kullanılan ifadeler bakımından uyumsuzluklar göze çarpmaktadır.

Üzerindeki yapının yıkılmasıyla arsa haline gelen taşınmazın ne şekilde değerlendirileceğine ilişkin anlaşmalarda aranan $2 / 3$ çoğunluğun pay ve paydaş çoğunluğu olarak anlaşılması gerekmektedir. Elbirliği halinde mülkiyet konusu taşınmaz ya da taşınmaz paylarının "ortakları"nın oybirliği ile hareket etmeleri; bu sağlanamıyorsa, TMK m. 703 gereği "malın devri, topluluğun dağılması veya paylı mülkiyete geçilmesi" ile önce elbirliği halinde mülkiyetin sona erdirilmesi gerekir. Yap1 yıkılmadan önce üzerinde kat mülkiyeti ya da kat irtifak1 mevcutsa "hisseleri oranında paydaşların 2/3 çoğunluğu" hesaplanırken, paylı mülkiyet için benimsenen sonuçlar dikkate alınmalı ve hem payların hem de paydaşların 2/3 çoğunluğu ile arsanın nasıl değerlendirileceğine ilişkin anlaşma yapılmalıdır. 
6306 Sayılı Kanun uyarınca yıkım işleminin ardından taşınmazın tapudaki sayfasında yer alan bütün şerhlerin "paylar üzerinde devam etmesi"nin anlamı ve sonuçları, şerh türleri bakımından ayrı ayrı değerlendirilmelidir.

Paylar üzerinde kişisel haklara ilişkin şerhlerin devam etmesi, kişisel hak sahiplerinin menfaatlerinin kentsel dönüşüm ile büyük ölçüde boşa çıkmasının önüne geçemeyecektir. Taşınmazın açık artırma konusu olması durumunda, bu açık artırmaya, paylar üzerinde şerh edilmiş olan özellikle arsa payı karşılığı inşaat, alım, önalım, gerialım ya da taşınmaz satış vaadi sözleşmelerinden doğan hakların sahiplerinin de katılabileceğinin öngörülmesi isabetli olurdu. Tasarruf yetkisinin kısıtlanmasına ilişkin şerhler ise, paylar üzerinde devam eder. Geçici tescil şerhlerinin, Kanun metninden anlaşlamamakla birlikte pay üzerinde devam etmesi gerektiği kabul edilmelidir.

6306 Sayılı Kanun ile getirilmiş olan riskli yapı niteliği, tapu sicilinde beyan işlemiyle gerçekleşecek olup, yapıların riskli olduğunun tespitine ilişkin kararın varlığı açıklanır ve bu konuda üçüncü kişilerin iyiniyet iddiaları ortadan kalkacaktır. Bu durum, kamu hukukundan kaynaklı bir kısıtlama niteliğindedir.

\section{KAYNAKÇA}

AKİPEK, Jale/AKINTÜRK, Turgut, Eşya Hukuku, Beta Yayıncılık, İstanbul 2009.

AKKAR, Z. Müge, Kentsel Dönüşüm Üzerine Batı'daki Kavramlar, Tanımlar, Süreçler ve Türkiye, Şehir Plancıları Odası Planlama Dergisi, S. 36, Ankara 2006, s. 29-38.

ALPÖĞÜNÇ, Erkan, "Arsa Payı Kavramı, Önemi, Hesaplanması, Düzeltme Davası" TBBD S. 89 Y. 2010, Ankara 2010, s. 493-506.

ATEŞ, Turan., 2/B'lerin Satışı ve Kentsel Dönüşüm, Bilge Yayınevi, Ankara 2013.

AYAN, Mehmet, Eşya Hukuku I, Zilyetlik ve Tapu Sicili, Gözden Geçirilmiş 13. Baskı, Seçkin Yayıncılık, Ankara 2016.

ÇAKALLI, Mehmet Emin, Kentsel Dönüşüm Projeleri ve İlgili İdari Yargı Kararları, Adalet Yayınevi, Ankara 2013

ÇOLAK, Nusret İlker, "Kentsel Dönüşüm/Kenti Dönüştürme ve Uygulanma Şekilleri”, Kocaeli Üniversitesi Hukuk Fakültesi Dergisi, C.4, S.7, Y. 2013 (E.T.: 03.09.2017 https://www.jurix.com.tr/article/4378

DİNÇER, Billur, Kentsel Dönüşüm ve Sosyal Adalet, Galatasaray Üniversitesi Sosyal Bilimler Enstitüsü Kamu Hukuku Anabilim Dalı Yayımlanmamış Yüksek Lisans Tezi, İstanbul 2014.

EREN, Fikret/BAŞPINAR, Veysel, Toprak Hukuku, 4. Baskı, Yetkin Yayınları, Ankara 2014. 
ERGÜL, Iş1, Tapu Sicilinde Beyanlar, Galatasaray Üniversitesi Sosyal Bilimler Enstitüsü Özel Hukuk Anabilim Dalı Yayımlanmamış Yüksek Lisans Tezi, İstanbul 2011.

ESENER, Turhan/GÜVEN, Kudret, Eşya Hukuku, 5. Baskı, Yetkin Yayınları, Ankara 2012.

GENÇ, Fatma Neval, “Türkiye'de Kentsel Dönüşüm: Mevzuat ve Uygulamaların Genel Görünümü”, Yönetim ve Ekonomi Manisa Celal Bayar Üniversitesi İktisadi ve İdari Bilimler Fakültesi Dergisi, C.15, S. 1, Y. 2008, s. 115130.

GÜNAY, Meryem, "Riskli Yapılarda Ortak Karar Protokolüne Karşı Açılan Davalar ve Hâkimin Müdahalesi", Kocaeli Üniversitesi Hukuk Fakültesi Dergisi, S. 14, Temmuz 2016, s. 105-133. Tam metin için bkz. https://jurix.com.tr/article/7498 (E.T.: 10.10.2017).

http://www.resmigazete.gov.tr/default.aspx

http://www.tdk.gov.tr

KARAKOCALI, Ahmet/TOKBAŞ, Hakan/SENCER, Sıla/KURŞUN, Ali Suphi, Sorularla Kentsel Dönüşüm Hukuku, Aristo Yayınevi, İstanbul 2017.

Kazancı Bilişim İçtihat Bilgi Bankası, www.kazanci.com

KOÇAKLI, Engin, Riskli alanlarda Maliklerin Uygulamasında 2/3 ile Karar Alınması ve $\mathrm{Bu}$ Alınan Kararlar Doğrultusunda İdarenin Kararları Uygulama Olanağı ve Görevi, Kocaeli Üniversitesi Hukuk Fakültesi Dergisi, S. 14, Temmuz 2016, s. 135-159. Tam metin için bkz. https://jurix.com.tr/article/7499 . (E.T.: 08.10.2017).

KÜRŞAT, Zekeriya, "6306 Sayılı Afet Riski Altındaki Alanların Dönüştürülmesi Hakkında Kanunun Özel Hukuk Alanındaki Etkileri”, Kentsel Dönüşüm Hukuku (YASİN, Melikşah/ŞAHİN, Cenk (ed.), İstanbul Üniversitesi S.S.ONAR İdare Hukuku ve İlimleri Araştırma ve Uygulama Merkezi Yayınları, İstanbul 2013, s. 21-50.

NOMER, Haluk Nami/ERGÜNE, Mehmet Serkan, Eşya Hukuku, Gözden Geçirilmiş 4. Bası, Oniki Levha Yayınları, İstanbul 2017.

OĞUZMAN, Kemal/SELİÇI, Özer/OKTAY-ÖZDEMİR, Saibe, Eşya Hukuku, 16. Tıpkı Bas1, Filiz Kitabevi, İstanbul 2013.

ÖZ, Turgut, "Kentsel Dönüşüm Kanunu Çerçevesinde Yapı Maliklerinin Üçte İki Çoğunlukla Alacakları Kararın İçeriğinin Amaca Göre Sinırlanabilmesi”, Kocaeli Üniversitesi Hukuk Fakültesi Dergisi, S.12, Ocak-Şubat 2016, s. 391-402. Tam metin için bkz. https://jurix.com.tr/article/7498 (E. T.: 09.10.2017).

ÖZMEN, Ethem Saba/AYDIN, Gülşah Sinem, Birlikte Mülkiyette (Paylı Mülkiyet/Elbirliği Mülkiyeti) Yapılan Kazandırıcı İşlemler ve 6036 Sayılı Kanun'a Dayalı Uygulama, Maltepe Üniversitesi Hukuk Fakültesi Dergisi, S. 1, Haziran 2015, s. 13-38. Tam metin için bkz. https://jurix.com.tr/article/5329 (E.T.: 05.10.2017).

ÖZMEN, Ethem Saba/VARDAR HAMAMCIOĞLU, Gülşah, Kat İrtifakı, Yenilenmiş 2. Bası, On İki Levha Yayınları İstanbul 2015.

ÖZSUNAY, E., 6306 Sayılı Kanun ve Uygulamalarına İlişkin Düşünceler, Vedat Kitapçllık, İstanbul 2015. 
SARAÇ, Murat, Kentsel Dönüşüm ve Gelişimi, Sosyal Boyutu, Kentsel Dönüşümden Doğan Hukukî Sorunlar, Çankaya Üniversitesi Sosyal Bilimler Enstitüsü Özel Hukuk Anabilim Dalı Yayımlanmamış Yüksek Lisans Tezi, Ankara 2014.

SİRMEN, Lale, Eşya Hukuku, Yetkin Yayınları, Ankara 2013.

ŞİMŞEK, Suat, Türkiye'de Kentsel Dönüşüm Uygulamaları, Seçkin Yayıncılık, Ankara 2014.

ÜNAL, Mehmet/BAŞPINAR, Veysel, Orman Hukuku, 4. Baskı, Savaş Yayınevi, Ankara 2017, (ÜNAL/BAŞPINAR, Orman)

ÜNAL, Mehmet/BAŞPINAR, Veysel, Şekli Eşya Hukuku, 8. Baskı, Savaş Yayınevi, Ankara 2016, (ÜNAL/BAŞPINAR, Eşya).

ÜSTÜN, Gül, Kentsel Dönüşüm Hukuku, Oniki Levha Yayınları, İstanbul 2014.

YILDIRIM, Ramazan, "İdâreye Taşınmaz Mal Kazandıran Bedelsiz Terk, Devir ve Temlikler", KTO Karatay Üniversitesi Hukuk Fakültesi Dergisi, C. 1, S. 2, Temmuz 2016, Sayfa: 13-22 (Tam metin için bkz. https://www.jurix.com.tr/article/5404 E.T.: 07.10.2017. 